\title{
Size Reduction Machine
}

by

V. Fricke

Westinghouse Savannah River Company

Savannah River Site

Aiken, South Carolina 29808

M. Bruns

J. Lee

DOE Contract No. DE-AC09-96SR18500

This paper was prepared in connection with work done under the above contract number with the U.S. Department of Energy. By acceptance of this paper, the publisher and/or recipient acknowiedges the U.S. Government's right to retain a nonexclusive, royalty-free license in and to any copyright covering this paper, along with the right to reproduce and to authorize others to reproduce all or part of the copyrighted paper. 


\section{DISCLAIMER}

This report was prepared as an account of work sponsored by an agency of the United States Government. Neither the United States Government nor any agency thereof, nor any of their employees, makes any warranty, express or implied, or assumes any legal liability or responsibility for the accuracy, completeness, or usefulness of any information, apparatus, product or process disclosed, or represents that its use would not infringe privately owned rights. Reference herein to any specific commercial product, process or service by trade name, trademark, manufacturer, or otherwise does not necessarily constitute or imply its endorsement, recommendation, or favoring by the United States Government or any agency thereof. The views and opinions of authors expressed herein do not necessarily state or reflect those of the United States Government or any agency thereof.

This report has been reproduced directly from the best available copy.

Available for sale to the public, in paper, from: U.S. Department of Commerce, National Technical Information Service, 5285 Port Royal Road, Springfield, VA 22161, phone: (800) 553-6847,

fax: (703) 605-6900

email: orders@ntis.fedworld.gov

online ordering: http://www.ntis.gov/ordering.htm

Available electronically at http://www.doe.gov/bridge

Available for a processing fee to U.S. Department of Energy and its contractors, in paper, from: U.S. Department of Energy, Office of Scientific and Technical Information, P.O. Box 62,

Oak Ridge, TN 37831-0062,

phone: (865)576-8401,

fax: (865)576-5728

email: reportsladonis.osti.gov 


\section{DISCLAIMER}

Portions of this document may be illegible in electronic image products. Images are produced from the best available original document. 


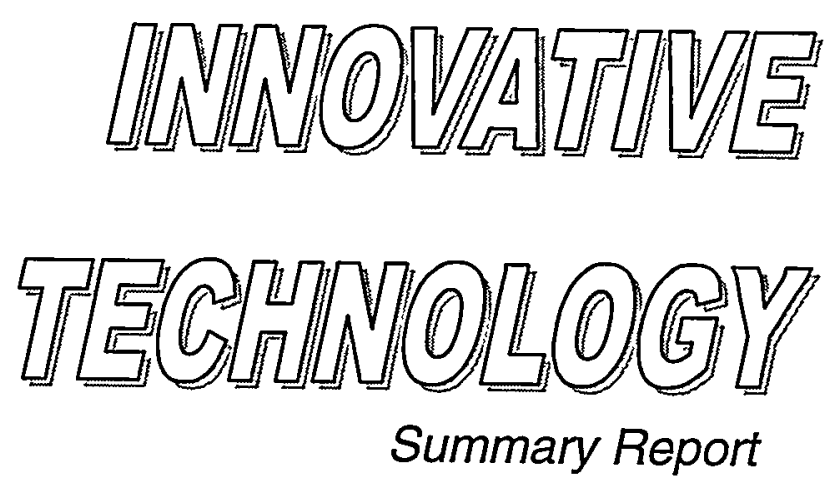

\section{Size Reduction Machine}

OST Reference \# 2395

Deactivation and Decommissioning Focus Area

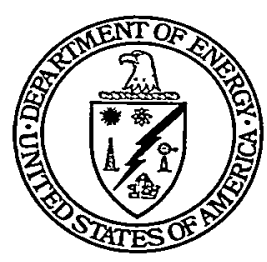

Demonstrated at 321-M Fuel Fabrication Facility Large Scale Demonstration and Deployment Project Savannah River Site Aiken, South Carolina 

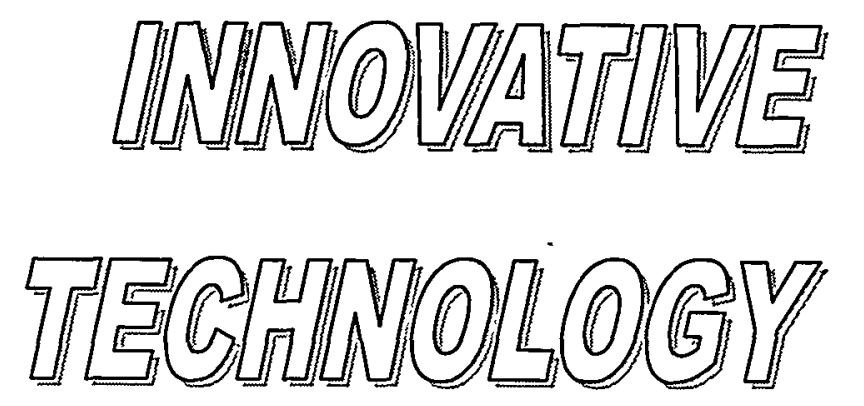

Summary Report

\section{Purpose of this document}

Innovative Technology Summary Reports are designed to provide potential users with the information they need to quickly determine if a technology would apply to a particular environmental management problem. They are also designed for readers who may recommend that a technology be considered by prospective users.

Each report describes a technology, system, or process that has been developed and tested with funding from DOE's Office of Science and Technology (OST). A report presents the full range of problems that a technology, system, or process will address and its advantages to the DOE cleanup in terms of system performance, cost, and cleanup effectiveness. Most reports include comparisons to baseline technologies as well as other competing technologies. Information about commercial availability and technology readiness for implementation is also included. Innovative Technology Summary Reports are intended to provide summary information. References for more detailed information are provided in an appendix.

Efforts have been made to provide essential data describing the performance, cost, and regulatory acceptance of the technology. If this information was not available at the time of publication, the omission is noted.

All published Innovative Technology Summary Reports are available on the OST web site at http://OST.em.doe.gov under "Publications." 


\section{TABLE OF CONTENTS}

1 SUMMARY

2 TECHNOLOGY DESCRIPTION

3 PERFORMANCE

4 TECHNOLOGY APPLICABILITY AND ALTERNATIVES

5 cost

22

6 REGULATORY AND POLICY ISSUES

7 LESSONS LEARNED

26

APPENDICES

A References

28

B Technology Cost Comparison

29 


\section{SECTION 1}

\section{SUMMARY}

The Size Reduction Machine (SRM) is a mobile platform capable of shearing various shapes and types of metal components at a variety of elevations. This shearing activity can be performed without direct physical movement and placement of the shear head by the operator. The base unit is manually moved and roughly aligned to each cut location. The base contains the electronics; hydraulic pumps, servos, and actuators needed to move the shear-positioning arm. The moveable arm allows the shear head to have six axes of movement and to cut to within $4^{\prime \prime}$ of a wall surface. The unit has a slick electrostatic capture coating to assist in external decontamination. Internal contamination of the unit is controlled by a high-efficiency particulate air (HEPA) filter on the cooling inlet fan. The unit is compact enough to access areas through a 36 -inch standard door opening.

The SRM was compared to the baseline technologies of portable band saw (PBS) and hand held hydraulic shear (HHS). The SRM cut loose thin-wall components and overhead items faster and more economically than the baseline technologies. When cutting heavy components at ground level, the SRM was only marginally faster than the baselines. The SRM hydraulic shear was less fatiguing for operators to use than the baseline technologies. As the SRM operation did not require the operators to repetitively lift heavy equipment loads, it provided a larger margin of safety from personal injury. It also provided a safer operation, since it allowed the operators to be stationed away from cut location and did not require the use of scaffolds to access the these locations.

\section{Technology Summary}

The Size Reduction Machine (SRM) was designed and built by Utility Engineering and Special Application Robotics (SAR). The SRM (Figure1) is a hydraulic shear attached to a hydraulically controlled arm that is mated to a manually deployed base unit. It allows shearing from 1 ' below floor level to $15^{\prime}$ above the floor without requiring the direct physical movement and placement of the shear head by the operator.

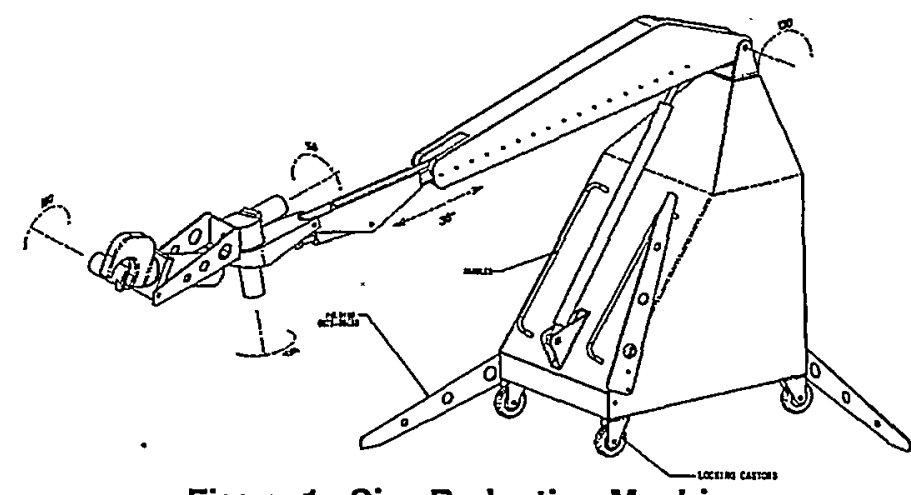

Figure 1. Size Reduction Machine

The shear can handle stainless steel metals that include schedule 40 pipe up to 4 " in diameter, 4 " $x$ $3 / 8$ " channel, $3 \times 3 \times 3 / 8^{\prime \prime}$ angle, $31 / 2$ " $\times 1 / 2$ " flat bar. The base unit contains the electronics, hydraulic pumps, tanks, servos, and actuators needed to move the shear positioning arm and operate the shear head and material gripper (handler). The functions are controlled by a tethered control panel that uses individual joysticks to control directional movements. The hydraulically controlled moveable arm provides the ability for the shear head to have 6 axis of movement and to cut to within 4" of a wall surface. The unit is electrically powered using a 220-volt, single phase, 60-amp source. The unit has an electrostatic capture coating finish that assists in external decontamination of the surface. Internal contamination of the unit is controlled by using a HEPA filter on the equipment cooling air inlet. Access to the equipment in the base unit is through two hinged doors with quick release closures. The unit is small enough to go through standard ' 3 ' wide doors to access work areas. 


\section{Problem Addressed}

For thirty-five years, the 321-M Facility fabricated fuel assemblies for the SRS production reactors. The manufacturing process, contaminated the casting, machining and storage areas and the material and equipment contained therein with uranium (alpha contamination). The main radiological concern while working in the area is making the uranium dust become airborne. Figure 2 provides a layout of the facility.

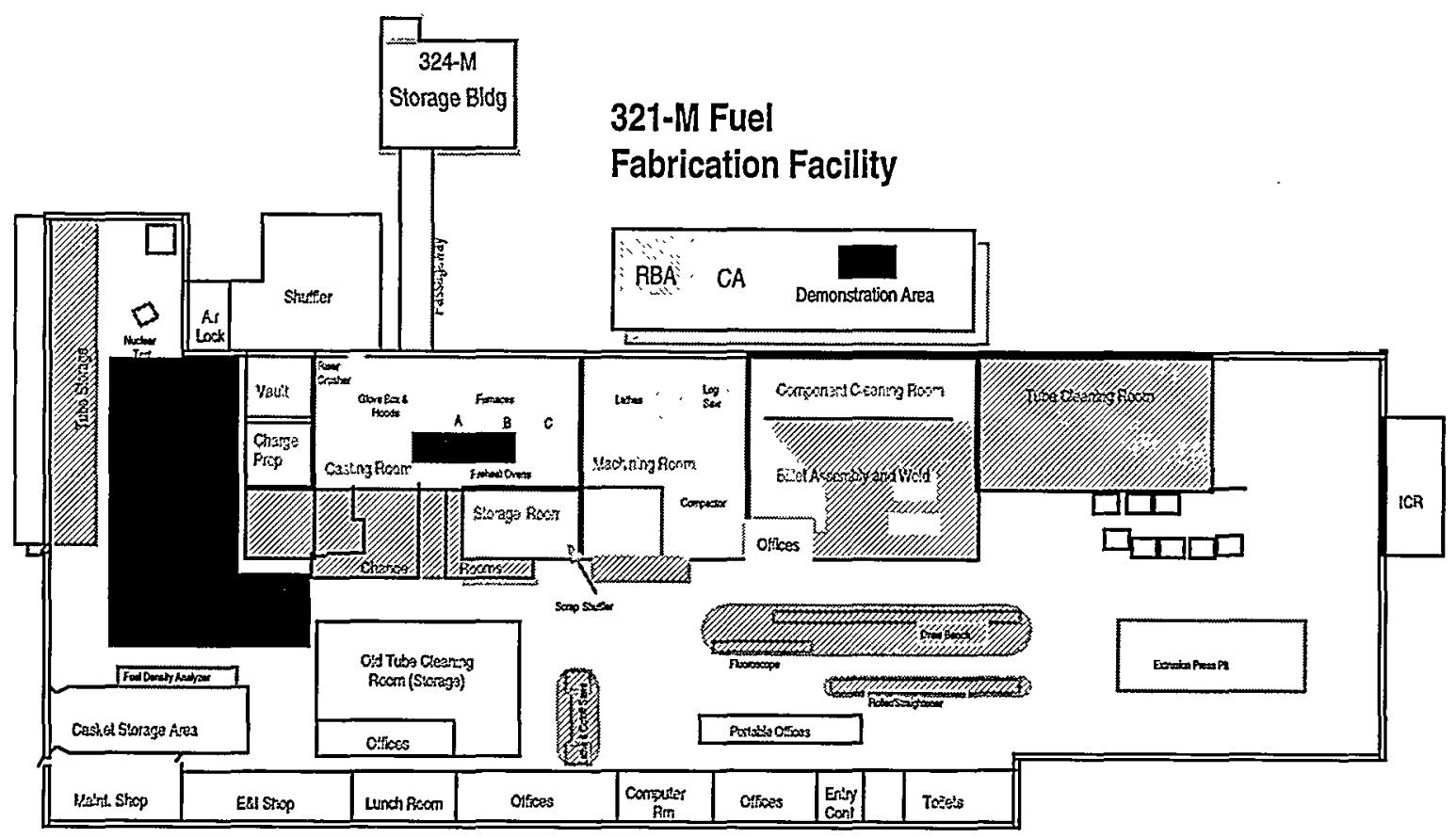

Figure 2.

Due to ongoing deactivation activities, excess piping, materials and components must be removed from these areas. In order to minimize the volume of Low Level Waste, items are size-reduced prior to placement into the waste containers. Historically, contaminated components are dismantled and size-reduced for disposal by mechanical methods in order to minimize the spread of contamination and prevent it from becoming airborne. Often access to areas is restricted due to door size or congestion in rooms. To perform size reduction work in these conditions has traditionally required the use of manual methods.

Two primary methods used in mechanical size reduction are sawing and shearing. Shearing methods typically produce a minimal amount of secondary waste debris. Both methods require operators to "manhandle" the heavy cutting equipment and therefore expose them to potential injuries. If the work is elevated, scaffolding or scissors lift (space permitting) are required to be erected to provide a safe work platform.

To minimize the fatigue and strain on the operator, a manually propelled Size Reduction Machine is needed that:

- takes the weight of the tool (shear) off the operator;

- allows the operator to remain off scaffolds

- provides a large degree of movement for placing the tool at the desired cutting locations, and

- is cost efficient to use. 
In the case of elevated work, the tool placement must be easy enough to operate that a ladder can be employed, if necessary, without scaffold erection to place rigging. The unit has to be small enough to move through standard door openings or operate in congested areas.

Larger, more robust self-powered platforms, such as track mounted or skid steer machines, are available for larger shears/tools. Because of the size of these platforms, they cannot fit through standard 36-inch doorframe without some disassembly and are cumbersome to use in congested spaces.

\section{How It Works}

To make a cut, two operators manually place the SRM base unit perpendicular to the cut location (Figure 3). If necessary, manual outriggers can be lowered and held in position with locking pins. Final positioning is performed hydraulically using the $20^{\prime}$ tethered control panel.

The positioning arm is operated from a separate hydraulic system (2500 psi, 3.0gpm) located in the base unit. Each hydraulic cylinder in the control arm system is positive controlled and locked in the position it is set if there is hydraulic pump failure.

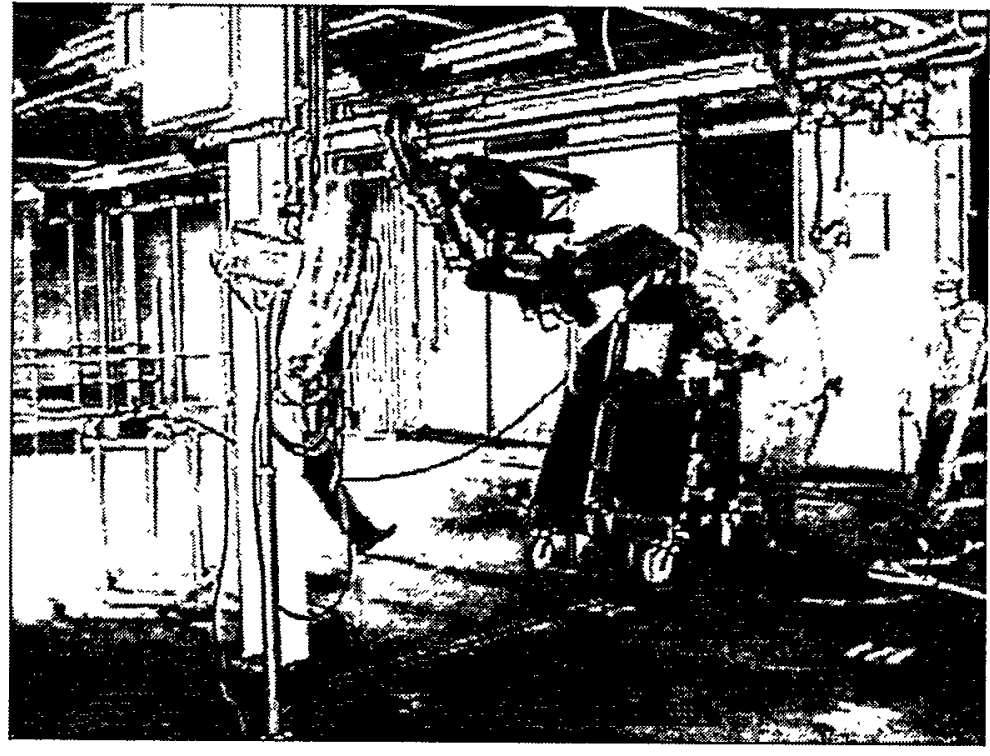

Figure 3. Picture of SRM shear being moved into position.

The cutting is performed with a Champion Shear model BPC-6, which utilizes a blade plunging cutter. This shear uses a modified " $\mathrm{V}$ " style guillotine blade mounted in a " $\mathrm{C}$ " shaped anvil frame. The blade passes through a recess in the anvil at the bottom of the stroke, severing the metal. The cutter weighs approximately 28 pounds. The shear operates from its own $5500 \mathrm{psi}, 1.2 \mathrm{gpm}$ hydraulic system mounted in the base unit. As part of the cutting cycle, a gripper device attached to the shear head holds the material being cut, and helps in cut alignment. If the cut piece is small enough in length, the gripper device can be used to lower it to the floor after the cut is made without rigging assistance.

\section{Potential Markets}

The SRM is an excellent size reduction tool for use in both contaminated and clean environments, where the work area is tight or congested. It can be used whenever interior metal pipe or component cutting is necessary. It is beneficial wherever deactivation or demolition work is being performed. The unit has been designed for use in contaminated spaces. Its exterior surfaces can be easily decontaminated, while the interior space is protected from contamination by a HEPA filter on the inlet/cooling fan. 


\section{Advantages Over the Baseline}

The innovative SRM technology has several advantages over the baseline methods that were used for comparison.

\begin{tabular}{|l|l|}
\hline \multicolumn{1}{|c|}{ Category } & \multicolumn{1}{|c|}{ Comment } \\
\hline $\begin{array}{l}\text { Speed of Cutting- } \\
\text { Small Loose Items Near Ground Level }\end{array}$ & SRM was faster than the baseline methods. \\
\hline $\begin{array}{l}\text { Speed of Cutting- } \\
\text { Heavy Loose Items Near Ground } \\
\text { Level }\end{array}$ & SRM was as fast as the baseline methods. \\
\hline $\begin{array}{l}\text { Speed of Cutting- } \\
\text { Fixed Items Overhead }\end{array}$ & SRM was faster than the baseline methods. \\
\hline Fatigue to Operator & $\begin{array}{l}\text { SRM was less fatiguing to use for the operators than } \\
\text { baseline methods. }\end{array}$ \\
\hline Ease of Use & $\begin{array}{l}\text { The SRM operation was relatively easy to learn and use } \\
\text { since its controls are color coded to match movement } \\
\text { directions of the unit. Operators adapted quickly to the } \\
\text { joystick operation controls. }\end{array}$ \\
\hline Injury Reduction/Safety & $\begin{array}{l}\text { The SRM has a lower potential for injury since it } \\
\text { eliminates rolling or mobile scaffold usage, and } \\
\text { eliminates potential for dropping heavy manual cutting } \\
\text { tools on hands or feet, and minimizes strains or sprains } \\
\text { due to continued lifting. Manual movement of the SRM } \\
\text { does introduce an extremely low potential for injury. }\end{array}$ \\
\hline Range of Components Cut & $\begin{array}{l}\text { The SRM cuts larger components than hand held } \\
\text { hydraulic shear can handle. The hand held hydraulic } \\
\text { unit could not cut larger stainless steel items. The band } \\
\text { saw blade would bind and stick frequently during the cut } \\
\text { cycle when cutting stainless steel. }\end{array}$ \\
\hline Cost Effectiveness & $\begin{array}{l}\text { The SRM is more cost effective in cutting thin-walled } \\
\text { components at both ground level and overhead than are } \\
\text { the baseline technologies. }\end{array}$ \\
\hline
\end{tabular}

Shortfalls or disadvantages for the SRM technology include:

- Speed of operation is dependent on the operators skills, abilities and visualization.

- Decontamination could be more costly than the baseline methods since the machine is not an expendable piece of equipment and is larger than the baseline equipment.

- More training is required to operate the SRM than baselines.

- Moving the unit by hand, while not overly difficult, would be faster and easier with a powered base platform.

- Shear blade must be centered with, and perpendicular to, the piece being cut for proper operation. Sometimes this requires a longer set up time to properly position the shear head for the cut. 


\section{Demonstration Summary}

This report covers the period from $7 / 99-8 / 99$.

\section{Demonstration Site Description}

The SRS Facilities Decommissioning Division (FDD), with the help of the Savannah River Technology Center (SRTC), sponsored the technology demonstration. Special Application Robotics designed and fabricated the Size Reduction Machine (SRM).

The SRM was demonstrated at the Savannah River Site's 321-M Fuel Fabrication Facility through the Large Scale Demonstration and Deployment Program. The demonstration was performed in a clean area with potentially contaminated overheads, and in the casting area which is a posted High Contamination Area (HCA). The items selected for size reduction fell into three groups, which are referred to as Case I, II, and III respectively in the rest of this report;

Case I Loose, thin-walled components at ground level in the contamination area - examples include chairs and unistrut;

Case II Loose, heavy structural shapes at ground level in the contamination area - examples include carts and racks made from angle iron;

Case III Overhead items in the clean area - examples include unistrut, angle, and small-bore pipe.

Figure 4 IIlustrates Case III, and Figure 5 illustrates Cases I and II.

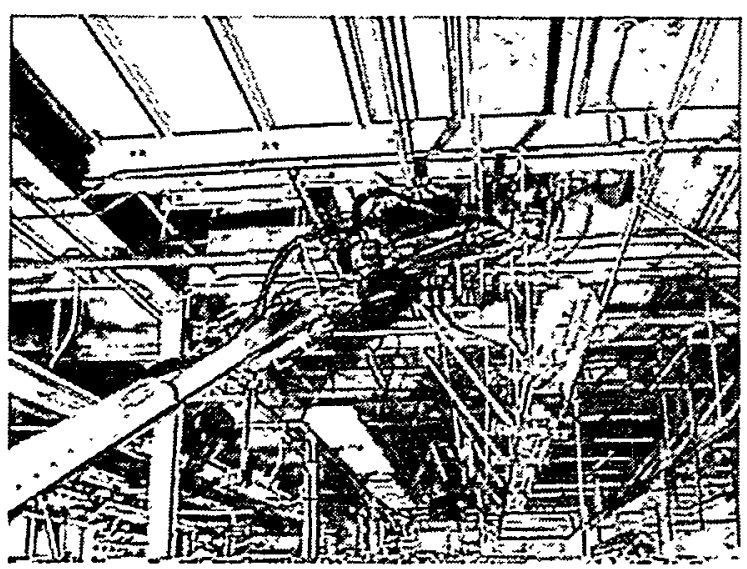

Figure 4. Cutting Items In The Overheads

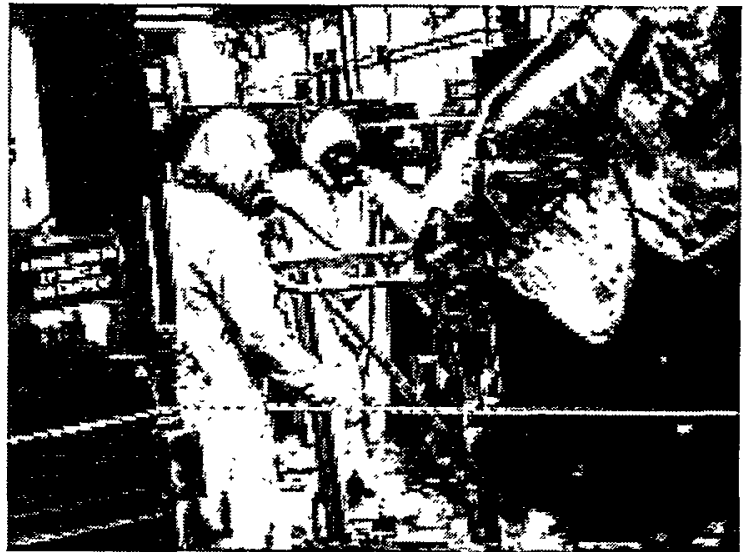

Figure 5. Cutting Loose Items (Carts), Contaminated Area, with Head of Shear Wrapped.

\section{Applicability}

This Size Reduction Machine represents an innovative technology that can be used at DOE sites and other similar government and commercial facilities that require pipe and components up to 4 " in size to be cut or size reduced. This is an economical alternative to other more costly self-powered shear units that can size-reduce larger components but will not fit through a standard 36 " door frame.

\section{Key Demonstration Results}

The SRM cut loose thin-wall components and overhead items faster and more economically than the baseline technologies. When cutting heavy components at ground level, the SRM was only 
marginally faster than the baselines. The SRM was demonstrated to cut stainless steel channel up to 4". It was safer to use and less strenuous for an operator to handle than the baseline equipment. Despite the SRM's weight of approximately 1400 pounds, it is easily moved by two operators. The gripper device attached to the cutting jaw was capable of holding cut pieces and lowering them the ground when the path is unimpeded. It also can assist in lowering pieces with rigging attached.

\section{Regulatory Issues}

This innovative shear is a segmentation (mechanical cutting) tool used for pipe and component cutting. No special regulatory permits are required for its operation and use. The machine uses standard hydraulic fluid that would require containment if a leak or line break were to occur.

\section{Technology Availability}

The Size Reduction Machine is currently a one-of-a-kind unit. Its demonstration at Savannah River Site in the 321-M facility was the first use for this device. The unit was designed and built by Utility Engineering in conjunction with Special Application Robotics in 12 weeks after placement of the order. Additional units could be built as required.

\section{Technology Limitations/Needs for the Future Development}

The SRM is manually moved. Set up time between cuts is sometimes lengthy if access to the cut location is restricted. The SRM must be realigned frequently to provide a clear path for each successive cut. This could be improved with the SRM base unit mounted on a proven moveable platform with a good range of motion. This would decrease the movement time between cuts and require no physical effort to move, further increasing the safety factor.

\section{Contacts}

\section{Technical}

Marley Bruns, Westinghouse Savannah River Company, (803) 725-1373; marley.bruns@srs.gov

\section{Vendor}

Dan Johnson, Utility Engineering/Special Application Robotics, $55015^{\text {th }}$ St., Suite 800 , Denver, CO, 80202-4256, (303)571-2828, SARobot@aol.com

R. Jon Stoucky, Mega-Tech Services(Champion Shear), 2804 Woodley Court, Jamestown, NC, 27282, (336)316-0707

\section{Management}

Jeffrey Lee, Principal Investigator, Westinghouse Savannah River Company, 803-725-0652; jeffrevw.lee@srs.gov

John Pierpoint, Project Manager, Westinghouse Savannah River Company, (803) 725-0649, john.pierpoint@srs.gov

\section{Department of Energy}

Martin Salazar, U.S. Department of Energy, Savannah River Operations Office; (803) 557-3617; martin.salazar@srs.gov George Mishra, U.S. Department of Energy, Savannah River Operations Office; (803)725-7239; george.mishra@srs.gov 
Department of Energy

John Duda, Federal Energy Technology Center, (304) 285-4217, jduda@fetc.doe.gov

\section{Licensing Information}

No licensing or permitting activities were required to support this demonstration. There were no specific state or federal regulations applicable to the use of the innovative or baseline methods other then those generally prescribed by OSHA regulations.

\section{Web Site}

The 321-M LSDDP Internet address is http://www.srs.gov/general/srtech/lstd/index.htm

\section{Other}

All published innovative technology summary reports are available online at http://em50.em.doe.gov. The Technology Management System, also available through the EM50 web site, provides information about OST programs, technologies, and problems. The OST Reference number for the Size Reduction Machine (SRM) is 2395. 


\section{TECHNOLOGY DESCRIPTION}

\section{Overall Process Definition}

\section{Demonstration Goals and Objectives}

The objective of this technology demonstration was to determine whether a manually propelled Size Reduction Machine (SRM) could increase production and reduce costs; particularly in overhead work, when operated in restricted and congested spaces. Another primary objective was to demonstrate whether the SRM could reduce fatigue and strain to the operator and therefore provide a safer tool to use than the comparable baseline methods. The baseline methods used for comparison were a portable band saw and a hand held portable hydraulic shear of similar weight to that mounted on the SRM.

\section{Description of Technology}

The SRM is split into four design areas; base unit, control box, moveable arm, and shear head.

The base unit (Figure 6), or body of the device is 34.75 " wide (without outriggers) by 48 " long by 72 " high, consisting of a triangular housing that holds the hydraulics, power, and control units. The housing also serves as the support structure for the shear arm. Mounted on casters, the base unit can be moved easily on smooth level surfaces and is counter weighted to offset the tipping moment when the main arm is extended fully in the horizontal position. In addition, extendable manual outrigger legs are attached to the outer housing to assist in stability.

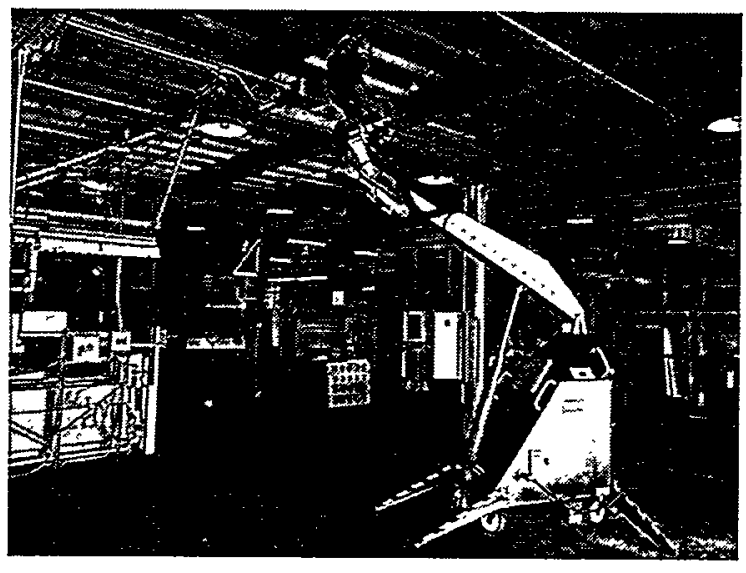

Figure 6. Base Unit

The inner portion of the base unit contains the hydraulic pumps, servos, and reservoirs needed to control and maintain the hydraulic shear and arm. The hydraulic system comprises a high pressure, $5500 \mathrm{psi}, 1.2 \mathrm{gpm}$, Enerpac pump, a valve pack and a reservoir tank for operating the shear. An additional pump system operating at $2200 \mathrm{psi}, 3.0 \mathrm{gpm}$ controls the support arm and head, using a separate reservoir feed tank. The control unit utilizes a bank of proportional valves, to allow feathering of the hydraulic components. An electronic control valve for each motor and actuator are mounted with the pumps. Other electrical and electronic control components are located in this space. There is additional space for future expansion within the base unit. 
A tethered control box with a 20 foot cable (Figure 7) on a rolling table, controls the unit and can be positioned for complete visual access to the cutting location. The control box can also be mounted on the operator by using a harness with waist and shoulder straps. The layout of the control box consists of three joysticks, an on-off switch, a retract/shear button, a retract/clamp gripper button. These control the various freedoms of motions of the designated mechanical component that is selected.

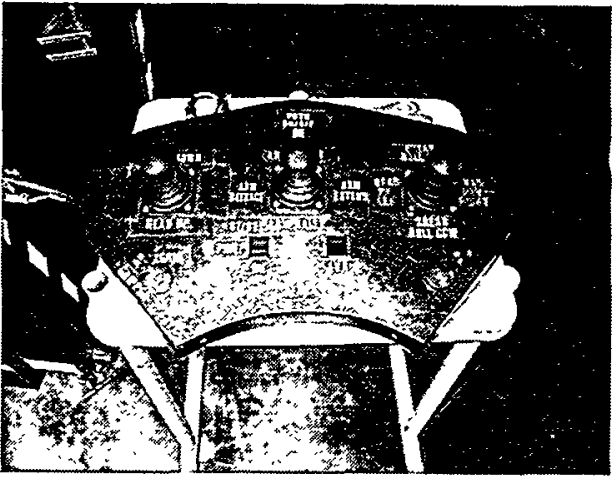

Figure 7. Control Panel on Rolling Table

Two motions can be utilized at the same time. The joysticks are potentiometers that control the proportional valves mounted with the hydraulic controls in the base unit. Movement of all devices is under positive control - a controlling button, joystick or switch must be held by the operator or the action stops. A single on/off button on the control box controls all power functions of the SRM. The relative position of moving parts is maintained if power is shut off or lost. A standby switch allows the cooling fan to run while the hydraulic pumps re-circulate at no pressure.

The hydraulic extension arm is attached to the top of the base unit through a pivot. The 3.5" bore, 36 " long hydraulic cylinder rotates about this point. The arm can extend 36 " horizontally using rollers, rails and a hidden second hydraulic cylinder with a 2" bore and 36 " stroke. The last degree of movement for the arm is based on a 2" bore, 6" long extension cylinder mounted on the end of the sliding arm just behind the head unit. Because of the three motions of the arm, anything from 1 foot below the floor level to 15 feet above the floor is accessible to the unit.

The shear head is adapted from a Champion Rescue Tool shear head (Figure 8). It is capable of cutting through 3 " $\times 3$ " stainless steel angle iron, 4" schedule 40 stainless steel pipe, and $31 / 2$ " $\times 31 / 2$ " stainless steel flat bar. The shear is mounted in a tool mount that has three axes of motion. The first motion is effected through a rotary actuator that allows the shear head to rotate 360 degrees around the $\mathrm{X}$-axis. The motion around the $\mathrm{Z}$-axis comes from a second rotary actuator. The final motion is through the $Y$-axis chain-drive, rotary actuator. Within reason, the freedom of motion for the shear should provide an adequate level of positioning to minimize movement of the base unit, except for gross lineup in the perpendicular direction.

Also mounted to the shear head is a gripper (Figure 9), that assists in holding the item being cut. The cut piece must still be rigged to lower it to the ground if cutting in the overhead position.

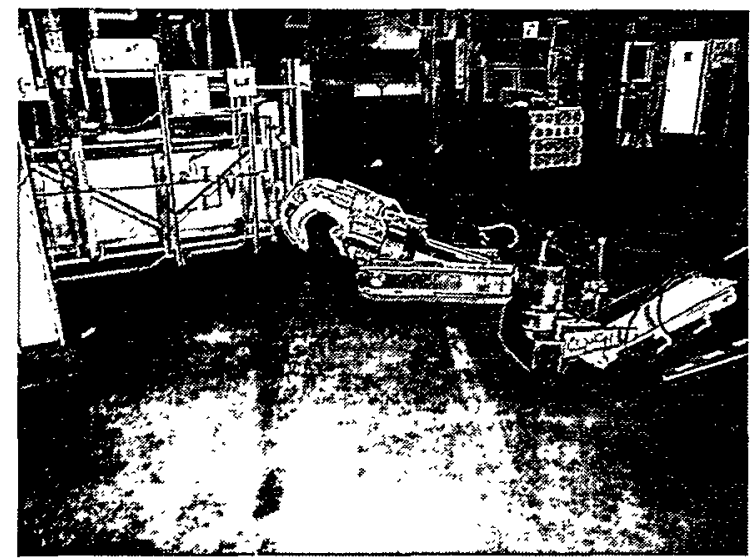

Figure 8. Champion shear head

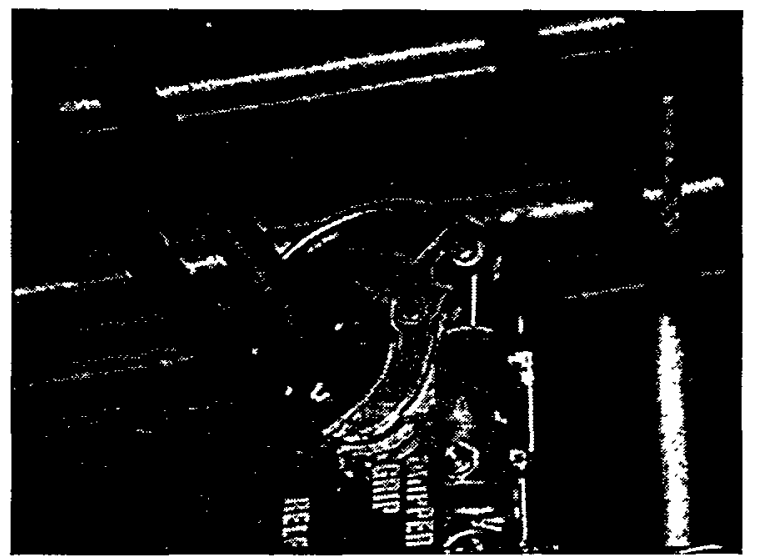

Figure 9. Gripper mounted to shear head 


\section{Basic Principle of Technology}

The SRM is a hydraulic assist device that allows the weight of the shear to be borne by the machine. This allows an operator to place the shear head at a location to be cut with minimal physical effort. Gross movement between cuts and for initial alignment of the SRM is manually controlled by two operators who manually move the base unit.

\section{Description of Key Elements}

\section{Loose Item Cutting (Contaminated Area) - Cases I and II}

Identical loose items were staged at the work location near the casting hood to take advantage of exhaust ventilation during the cutting operation. Items to cut in this grouping consisted of carbon steel, straight back and swivel chairs, and heavy-duty stainless steel process carts made of 4" stainless steel channel and $11 / 2$ " stainless pipe.

A crew of three was needed to operate the SRM. Two operators were located inside the posted Airborne Radioactivity Area (ARA) and the third was located in the high contamination area (HCA). This person functioned as the control operator and standby person. The SRM was positioned so that the head and arm crossed into the ARA while the base unit and controls were located in the HCA (Figure 10). The operators in the ARA positioned items to be cut by the shear. When cutting carts, the operators in the ARA moved the cart to a position perpendicular to the shear head. Some intended cuts could not be made on the carts because the cut location did not allow adequate clearance for the shear jaw.

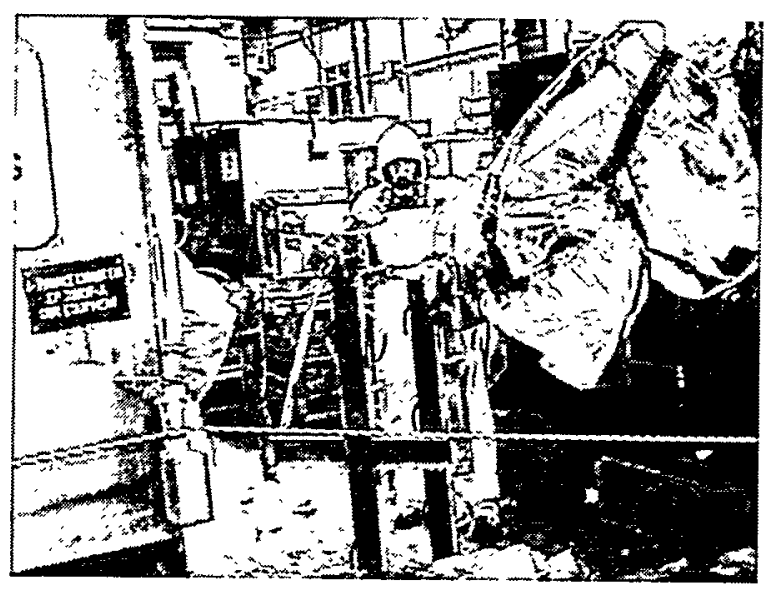

Figure 10. Use of SRM in Airborne Radioactivity Area

For the baseline methods the crew size was also three operators. Two operators performed the cutting in the ARA and the third stood by in the HCA to assist. The items were cut using both methods. The hand held hydraulic shear could not cut the 4" stainless channel and struggled on the $11 / 2 "$ stainless angle, which it eventually cut through. The portable band saw had trouble cutting the 4" stainless channel. The blades would frequently stick or break during the cutting process, producing significant down-time for blade replacement.

Cutting loose items at floor level with the SRM proved to be equivalent to and in some cases faster than the baseline methods. However, not all cuts could be made with the SRM because of jaw clearance requirements. The SRM could cut up a chair with six cuts in about $21 / 2$ minutes. The baseline methods had similar times, but required one operator to position the chair while the other operator supported and operated the cutting tool. SRM proved to be less fatiguing to the operators and reduced the potential for injury. The SRM also cut 4" stainless channel with ease; this was difficult or impossible with the portable band saw and hand held hydraulic shear.

\section{Overhead Cutting (Potentially Contaminated) - Case III}

In this category, $3 / 4$ " and $11 / 2$ " schedule 40 , carbon steel pipes were removed, and an overhead rack made of schedule 40 unistrut and $11 / 2$ " $\times 11 \frac{1}{2}$ " $\times 3 / 8$ " carbon steel angle supports was dismantled. 
A crew of three was needed to operate the SRM. To make a cut, the SRM was rolled to the cut location by two operators and roughly aligned to the cut area. An operator would then access the item to be cut using a ladder to attach appropriate rigging. For safety reasons, cut and drop was not allowed. Final alignment and placement of shear head was made by the control operator. The gripper mounted to the side of the shear jaw was then clamped to aid in aligning the cut. The cut was made and the cut piece lowered to the ground for disposal using the rigging. The gripper was able to hold larger diameter materials and could lower it to the ground when no obstructions were present. The SRM was able to access very tight and congested places to make the required cuts.

The crew size for the baseline methods was also three operators. The baseline methods utilized a motorized scissors lift with two operators to access the cut locations. Cuts made with the portable band saw were made by one operator while the second operator held the part being cut. The cut item was then handed to the third operator located on the ground for disposal. For the hand held hydraulic shear, overhead cuts would require both operators to hold the shear until the cut was initiated. Upon cut completion, one operator caught the cut item and the other handled the weight of the shear down to the scissors lift handrail. The cut item was handed down to the ground operator for disposal.

Early in the demonstration, it was determined that the hand held hydraulic shear was unsafe to use for overhead cutting because of its violent cocking action during a cut and the difficulty of controlling it due to its weight. While lighter than the hand held hydraulic unit, the portable band saw did make the operator more tired than the SRM during overhead cutting.

The Size Reduction Machine (SRM) was as fast as the baseline methods in overhead cutting when rigging time is discounted. Cut time improved as operator experience in using the SRM machine was gained. A motorized scissors lift was used to access the cut areas for the baseline cutting methods. This equipment greatly enhanced the baseline efficiency because it could be driven to the next cut location. Operation of the SRM proved to be safer because it removed the operator from proximity to the cutting tool and cutting operation. The SRM was less strenuous for the operator because the weight of the cutting tool was supported by the unit. This was particularly true for overhead cuts. The SRM also was able to cut larger items much faster than the baseline methods.

\section{Specific DOE Application for this Demonstration}

Within the DOE complex, waste minimization is a requirement. To meet this requirement, solid wastes must be size-reduced to fit into a waste container or to allow placement in the waste container in the most efficient manner. The SRM meets this requirement and performs in a costeffective manner while enhancing safety.

\section{System Operation}

\section{Operational Parameters}

The SRM can operate in clean or contaminated conditions at all ambient temperatures. The demonstration was performed when temperatures exceeded 100 degrees Fahrenheit and $65 \%$ relative humidity, but there were no equipment problems due to temperature. A smooth and level concrete floor is preferred so that the unit can be easily moved manually. Although the unit is equipped with outriggers, it was operated extensively without them with no stability problems, even for overhead positions.

\section{Material, Equipment, Service Requirements and Operating Requirements}

The SRM is powered by $220 / 208$ volts, $60 / 70$ amps. Standard hydraulic fluid is required for both hydraulic units. Expendable HEPA filters are installed on the inlet and outlet of the air cooling 
system. A hydraulic filter on the low-pressure 2500 psi unit requires replacement after 200 hours of operation.

The portable band saw required $110 / 120$ volts, 15 amps power. Expendables included band saw cutting blades.

The hand-held hydraulic shears used 1 quart of gasoline per hour of operation and required occasional changes of engine oil and hydraulic fluid make-up.

\section{Manpower Requirements and Training Requirements}

A team of Facility Decommissioning Division (FDD) personnel was assembled to perform the demonstration. The team was made up of the following personnel:

- Two from the Operations organization

- Two from the Maintenance organization

- One from Engineering organization

- One from the Radiological Support organization

The same team provided support for mechanical assembly, service, and repair. No other site support personnel were required. A basic operation manual was supplied as part of the vendor's deliverable package and was used to provide initial instruction on the operation of the unit. Two days of hands-on training were held, which included one day of practice cutting clean angle iron racks to familiarize the operators with the manipulation of the unit.

\section{Secondary Waste}

Unlike the band saw, the shear on the SRM does not generate any cuttings or other secondary waste. An expendable HEPA filter on the inlet cooling air intake is disposed of as low-level waste. Some secondary waste generation was necessary to protect both the SRM and the HHS from contamination; the machine was fully wrapped in plastic, except for the shear jaws and filter areas, prior to moving it into the contaminated area. The SRM unit, including the shear jaw was successfully decontaminated for free release after the demonstration.

\section{Operational Concerns/Risks/Safety}

The unit was designed with a $2 X$ strength safety factor. The unit is capable of carrying 200 pounds on the fully extended boom before reaching tipping limits. The hydraulic power units have standard bleed-back features and internal relief valves for protection against overpressurization. A Job Hazard Analysis (JHA) was conducted prior to the start of the demonstration to identify potential safety problems during the use of the SRM. As a result of this analysis, some precautions were implemented to enhance the safe use of the machine. A spill of hydraulic fluid from broken or burst lines was identified as a potential environmental hazard, and a spill kit was kept readily available. 


\section{SECTION 3}

\section{PERFORMANCE}

\section{Demonstration Plan}

As part of the D\&D mission at DOE sites nationwide, DOE and its contractors must remove large quantities of piping, conduit and light structural components from contaminated areas to prepare buildings for demolition. The SRM, equipped with a Champion Shear, is capable of handling piping and structural shapes up to 4". This provides a system that can cut larger items than baseline methods currently in use, while accessing areas that are not easily accessible with conventional hand-held equipment.

\section{Demonstration Site Description}

The SRM was demonstrated at the Savannah River Site's 321-M Fuel Fabrication Facility. The demonstration was performed in a clean area with potentially contaminated overheads and in the casting area, which is a posted High Contamination Area (HCA).

\section{Performance Objectives}

The objective of the demonstration was to use the manually propelled SRM to cut and size-reduce an assortment of materials both in the overhead and at ground level, to compare it with baseline technologies on the basis of:

- ease of use

- speed of production (making cuts)

- cost of use

- operational safety

- ease of decontamination

- operator fatigue

\section{Elements of Demonstrations}

The items that were size-reduced fell into three groups:

- loose light items in the contaminated area at ground level, such as chairs - Case I

- loose heavy items in the contaminated area at ground level, such as stainless steel transport carts - Case II

- fixed items such as angle, pipe and unistrut in the clean area overhead - Case III

For each group, identical items were cut and the same number of cuts was made using both the innovative technology and the two baseline methods. Each group was finished before proceeding to the next category to keep data collection separate.

Overall, one hundred sixty-four cuts were made using each method during this demonstration. Seventy one cuts were made in the overhead area with each method. The balance of the cuts, ninety-three, were made in the High Contamination Area (HCA) which was posted as an Airborne Radioactivity Area (ARA) during the cutting operation. The materials that were cut ranged from carbon steel, light gage tubing, to $4^{\prime \prime} \times 3 / 8^{\prime \prime}$ stainless steel channel. 


\section{Results}

The SRM cut loose thin-wall components and overhead items faster and more economically than the baseline technologies. When cutting heavy components at ground level, the SRM was only marginally faster than the baselines. The SRM hydraulic shear was less fatiguing for operators to use than the baseline technologies, despite the fact that the machine had to be repositioned manually. It provided better safety and less chance of injury since it did not subject the operator to lifting heavy loads repetitively, especially when working overhead, and did not require the operators to be on a scaffold or scissors lift to get to the cut locations. 


\section{SECTION 4}

\section{TECHNOLOGY APPLICABILITY AND ALTERNATIVES}

\section{Competing Technologies}

The SRM was compared to the baseline technologies of a portable band saw and a hand held hydraulic shear. There are other technologies (Brokk, MWP by Eagle) available, which are combinations of higher tech, more robust, more remotely controlled, and larger platform units. In general, these technologies cost more than the Size Reduction Machine (SRM). The SRM has a niche between the hand held technologies and these larger platforms. Because of its small size and ability to pass through a standard 3' door frame, it could be valuable tool for size reduction.

The SRM, however, should not be considered a stand-alone technology. Because of its inability to perform certain cut locations and configurations because of the shear jaw size, it should be used in conjunction with and supplement a baseline technology. If used in this combination, an efficient size reduction process can be established to best utilize its capabilities.

Table 1. Comparison of the Innovative SRM with the Baseline and Other Alternative Technologies

\begin{tabular}{|c|c|c|}
\hline Technology & Advantages & Disadvantages \\
\hline SRM & $\begin{array}{l}\text { - Can cut up to 4" SS channel } \\
\text { - Can pass through standard } 3 \text { ' door } \\
\text { - Can reach up to } 15^{\prime} \text { and down to } 1^{\prime} \text { below } \\
\text { floor level } \\
\text { - Easy to learn to operate because of } \\
\text { color-coded controls } \\
\text { - Capture-coated (slick, hard finish) to } \\
\text { assist in decontamination efforts } \\
\text { - Removes operators from cut location and } \\
\text { harms way }\end{array}$ & $\begin{array}{l}\text { - Somewhat bulky and difficult to maneuver in } \\
\text { very tight locations. } \\
\text { - Can not make all cuts due to shear jaw size. } \\
\text { - Blades cost more then baseline } \\
\text { - Blades take longer to change out than } \\
\text { baseline } \\
\text { - Larger area to decontaminate than baseline } \\
\text { - Requires hydraulic fluid (spill potential) } \\
\text { - Must have } 4^{n} \text { clearance for shear anvil and } \\
\text { gripper jaw }\end{array}$ \\
\hline Portable band saw & $\begin{array}{l}\text { - Tool weight relatively low } \\
\text { - Portable } \\
\text { - Blades easy to change } \\
\text { - Easy to learn to use } \\
\text { - Blades are fairly economical and } \\
\text { commonly available } \\
\text { - Uses standard } 110 \text { volt power } \\
\text { - Can be used while dressed out with } 2 \\
\quad \text { pair of gloves fairly easily }\end{array}$ & $\begin{array}{l}\text { - Requires frequent blade changes when cutting } \\
\text { stainless steel } \\
\text { - Places operator at cut location } \\
\text { - Requires tool to be lifted above the chest for } \\
\text { overhead cutting. } \\
\text { - Makes loose waste fines (cuttings) } \\
\text { - Not easily decontaminated (expendable, throw } \\
\text { away, becomes LLW) }\end{array}$ \\
\hline $\begin{array}{l}\text { Hand Held } \\
\text { Hydraulic Shear }\end{array}$ & $\begin{array}{l}\text { - Portable } \\
\text { - } \text { work location. } \\
\text { - Small amount of hydraulic oil (1 gallon) } \\
\text { if hose fails } \\
\text { - Economical to operate }\end{array}$ & $\begin{array}{l}\text { - Heavy and hard to handle } \\
\text { - } \quad \text { Places operator at cut location } \\
\text { - } \text { overhead culting. } \\
\text { - Switch difficult to operate with } 2 \text { pair of gloves } \\
\text { - Gasoline engine must be located outside } \\
\text { requiring long supply hoses } \\
\text { - Not easily decontaminated without } \\
\text { disassembling jaws. } \\
\text { - Shear scissors cocks when cutting (safety } \\
\text { issue) } \\
\text { - Blade change out takes a long time. } \\
\text { - Requires two operators to place and hold tool } \\
\text { when working overhead }\end{array}$ \\
\hline
\end{tabular}




\section{Technology Applicability}

The SRM was used to size-reduce piping and components in the 321-M facility at the Savannah River Site in both potentially contaminated as well as contaminated areas.

- This technology would be an excellent supplement to baseline methods where size reduction of piping, conduits, and components less than 4 " is necessary.

- It is faster then baseline methods.

- It removes the operator from the cut location and out of harms way.

- It removes the weight of the cutting tool from the operator, providing a less strenuous environment and lessening the potential for operator injury.

- It is capable of handling cut components to the ground if adequate clearance exists.

- The unit has been designed to make external decontamination easier and preclude internal contamination of the base unit.

- The overall size of the unit is appropriate for the shear tool that is mounted to the control arms.

\section{Patents/Commercialization/Sponsor}

The Size Reduction Machine (SRM) was designed and built by Utility Engineering under contract to Special Application Robotics(SAR) located Loveland, CO.

The completed unit has not been patented and is made up of many commercially available off the shelf parts. The unit is one-of-a-kind, but additional units could be fabricated using the same design with lessons learned incorporated into any additional units. The Department of Energy which sponsored this through the Office of Science and Technology (EM-50) hold all rights to this design package. Release of these design rights would have to be obtained from this government office. 


\section{SECTION 5}

\section{COST}

\section{Introduction/Methodology}

This section compares the innovative Size Reduction Machine (SRM) to two baseline cutting technologies: the portable band saw (PBS) and the hand-held shear (HHS). The objective of this analysis is to assist decision makers in their selection of the optimum cutting technology.

The SRM was designed and built by Utility Engineering / Special Application Robotics. Savannah River Site purchased the SRM, trained site workers to operate it, and used it during this technology demonstration on loose thin-walled components, loose heavy structural shapes, and fixed overhead items in the 321-M Fuel Fabrication Facility.

Portable band saws used during the technology demonstration were owned and operated by the Facilities Decommissioning Division's work force.

The hand-held shear is a rented piece of equipment. It was rented from the site's portable equipment commodity management center (PECMC) and used by the division's work force.

As part of the demonstration, the PBS and HHS cut identical items to those cut by the SRM.

This analysis strives to develop realistic estimates that represent actual dismantlement work at the U.S. Department of Energy's Savannah River Site. It is a limited representation of actual cost because some of the observed costs were adjusted or eliminated to allow for first time use inefficiencies and unique SRS administrative requirements. Allowances were also made in the cost analysis work-up to promote an equivalent or "apples-to-apples" comparison across the three cutting technologies.

For example, when cutting fixed overhead items, "rig time" was not included for the SRM technique because cuts made with the PBS or HHS did not require pipes, unistrut, angle iron, or rods to be rigged. In addition, the time to lower items cut overhead proved to be inconsequential (on the order of seconds); therefore, "lowering time" was excluded for each of the demonstration technologies. Only those adjustments that would not distort the fundamental elements of the observed data (i.e., would not change productivity rates, etc.) were included.

Cost and performance data was collected for both the innovative and baseline technologies. The following cost elements were identified from the Army Corps of Engineers (ACOE) Hazardous, Toxic, and Radioactive Waste Remedial Action Work Breakdown Structure and Data Dictionary (HTRW RA WBS):

- Mobilization

- Dismantlement - Cutting

- Demobilization

Mobilization includes an equipment inspection before each use, personal protective equipment for those jobs in the 321-M contaminated area, and provision of a B-25 (for low level waste) or a roll-off scrap container to hold items cut during the demonstration.

Dismantlement includes all direct and indirect activities associated with cutting thin-walled components (Case I), heavy structural shapes (Case II), and overhead fixed items (Case III).

Demobilization includes the removal of the B-25 or the roll-off scrap container once it is full. 


\section{Cost Analysis}

Data was collected during the performance of the baseline technology and the demonstration of the innovative technology. Time to complete a job was recorded. Labor hours were multiplied by the respective worker's charge rate. As applicable, equipment and material cost was added to labor cost. Unit costs were determined based on the number of cuts.

Site labor rates used in the analysis were those in effect for the SRS site labor agreement. Crews for the various activities were based on the data collected. Time for personnel supporting the demonstration aspects of the activity (oversight, data recording, etc.) was not included in the labor cost subtotals. Individual charge rates (the fully burdened charge rates) covered the worker's salary and benefits: Site overheads were omitted from the analysis. Quality assurance and taxes were omitted from the analysis.

The Size Reduction Machine (SRM) was purchased from Utility Engineering / Special Application Robotics for $\$ 127,000$. The machine has an expected life of 4000 hours. After factoring in the cost of periodic maintenance and blade replacement, the extended cost per hour of use is estimated to be $\$ 36.53 /$ hour. (Reference Table B-1 in Appendix B.)

The Portable Band Saw (PBS) extended cost per hour of use is estimated to be $\$ 6.89 /$ hour. This rate included the purchase and use of the band saw, the rental of a motorized scissors lift to get the band saw in position for overhead cuts, and the purchase and use of safety harnesses for the work crew. Blade replacement was also included in the equipment unit rate. PBS maintenance was not considered because the band saw was used until it failed and then discarded. (Reference Table B2 in Appendix B.)

The Hand Held Shear (HHS) extended cost per hour of use is estimated to be $\$ 10.62 /$ hour. This rate included the rental of a hand held hydraulic shear, the rental of a motorized scissors lift to get the hand held shear in position for overhead cuts, and the purchase and use of safety harnesses for the work crew. Blade replacement was also included in the equipment unit rate. HHS maintenance was not considered because the shear was a rental piece of equipment and these costs were built into the rental fee. (Reference Table B-3 in Appendix B.)

For fixed cost activities that are independent of the number of cuts made, costs were calculated as lump sum costs instead of unit costs. The mobilization and demobilization activities for the demonstrations were typical fixed cost activities. They were treated as lump sum costs and expressed on the basis of the job (e.g., the fixed costs associated with cutting overhead items). For this technology demonstration, the fixed costs for the innovative and baseline technologies were the same. From a cost comparison standpoint, they cancelled each other out. On the other hand, unit costs were dependent on the quantity of cuts made and varied depending on the cutting technique and the type of items cut. For both the innovative and baseline technologies, the unit costs were expressed in terms of dollars spent per cut.

A comparison of production rates is shown in Table 1. (The raw data to support production rate calculations can be found in Tables B-4 through B-12 in Appendix B.) 
Table 1. Cutting Technology Production Rates

\begin{tabular}{|l|c|c|c|}
\hline & Case I & Case II & Case III \\
\hline & (thin-walled components) & (heavy structural shapes) & (overhead fixed items) \\
\hline \hline SRM & 0.83 minutes/cut & 3.03 minutes/cut & 2.81 minutes/cut \\
\hline PBS & 2.36 minutes/cut & 3.25 minutes/cut & 3.04 minutes/cut \\
\hline HHS & 1.36 minutes/cut & 3.80 minutes/cut ${ }^{*}$ & 4.00 minutes/cut \\
\hline
\end{tabular}

"The HHS could not cut all the heavy structural shapes. If the elapsed time for these failed attempts had been factored into the calculation, the per cut time for Case II for the hand held shear would have been greater.

The Size Reduction Machine takes less time to perform a cut in all three cases. The most dramatic advantage is realized when cutting thin-walled components and overhead fixed items. The SRM is only slightly better than the baseline for cutting heavy structural shapes.

A comparison of unit costs for the Dismantlement cost element is shown in Table 2. (Reference Tables B-4 through B-12 in Appendix B.)

Table 2. Cutting Technology Unit Costs

\begin{tabular}{|l|c|c|c|}
\hline & Case I & Case II & Case III \\
\hline & (thin-walled components) & (heavy structural shapes) & (overhead fixed items) \\
\hline \hline SRM & $\$ 2.33 /$ cut & $\$ 8.51 /$ cut & $\$ 6.50 /$ cut \\
\hline PBS & $\$ 5.47 /$ cut & $\$ 7.53 /$ cut & $\$ 7.71 /$ cut \\
\hline HHS & $\$ 3.23 /$ cut & $\$ 9.08 /$ cut $^{\star}$ & $\$ 10.38 /$ cut \\
\hline
\end{tabular}

*The HHS could not cut all the heavy structural shapes. If the elapsed time for these failed attempts had been factored into the calculation, the dollars spent per cut for Case II for the hand held shear would have been greater.

A quick analysis indicates the SRM is less costly when thin-walled components and overhead fixed items are cut. When heavy structural shapes must be cut, the portable band saw and the hand held shear are less expensive than the size reduction machine.

\section{Cost Conclusions}

- The Size Reduction Machine was clearly the optimum cutting technique when loose thin-walled components (e.g., schedule 10 tubing) and overhead fixed items (e.g., schedule 40 carbon steel pipe, schedule 20 carbon steel unistrut, $1 / 4$-inch thick carbon steel angle iron, and $1 / 2$-inch diameter carbon steel rod) were cut.

- The Size Reduction Machine was comparable to the baseline technologies when cutting loose heavy structural shapes (e.g., schedule 40 stainless steel pipe, 3/8-inch stainless steel angle iron, and 3/8-inch stainless steel channel).

- Various heavy structural shapes could not be cut by the Hand Held Shear (ref. Case II) and were not included in the database. If these failures had been factored into the cutting technology selection process, the Size Reduction Machine would have been the favored technology over the Hand Held Shear in not only Case I and III, but also Case II.

- If the safety benefits of using the Size Reduction Machine could be factored into the technology's unit cost calculation, deployment of the SRM would prove to be even more 
advantageous. For example, the tethered control panel allows the worker to operate the SRM from a comfortable distance, thereby removing the worker from harm's way. Use of the SRM with its long reach and six degrees of freedom eliminates the need for scaffolding. Finally, use of the SRM means heavy cutting equipment does not need to be physically manipulated repetitively. Eliminating this physical handling of the portable band saw and the hand held hydraulic shear could reduce the number and severity of careless mishaps or injuries brought on by operator fatigue.

- The use of motorized scissors-lift on this demonstration may have biased the results somewhat against the SRM. The cost of the scissors-lift was at very favorable government-owned equipment rental rates peculiar to SRS. There are also situations where a scissors-lift could not be used, yet the SRM could still access the cut location because of its 30 foot reach. If these factors could have been eliminated, the SRM results would have been even more favorable.

- As the operators gained more experience, the overall setup time for making cuts decreased. This learning curve would tend to reduce unit costs for the SRM. 


\section{SECTION 6}

\section{REGULATORY AND POLICY ISSUES}

\section{Regulatory Considerations}

- The innovative shear technology is a segmentation tool used for cutting pipe and components. No special regulatory permits are required for its operation and use.

- Applicable parts of OSHA CFR 1910 and 1926 for safety, demolition and machine operation apply to this piece of equipment

\section{Safety, Risks, Benefits, and Community Reaction}

\section{Worker Safety}

Enhancing worker safety is one of the advantages of the Size Reduction Machine. The safety to worker is increased because it:

- removes the worker from harm's way

- carries the weight of the cutting tool, thereby reducing the risk of stress injury

- lessens worker fatigue

- eliminates the potential of dropping cutting tool on hands or feet.

- eliminates the necessity of accessing and working off an elevated scaffold or scissors lift

\section{Community Safety, Community Reaction and Socioeconomic Impacts}

- There is no direct adverse safety impact on the community as a result of using the SRM.

- It would be expected to be a positive reaction since it would help remediate buildings in a safe, cost-efficient manner.

\section{Environmental Impact}

- There is no adverse impact on the environment using the SRM. A broken hydraulic line poses a small risk of release of some hydraulic fluid. However, this type of failure would be immediately evident and inside a building, so such a spill would be easily and quickly mitigated. 


\section{SECTION 7}

\section{LESSONS LEARNED}

\section{Implementation Considerations}

- Workers with dexterity and good spatial visualization skills should be chosen to run the SRM.

- An experienced and seasoned operator could greatly reduce the cutting time.

- Components and metal being cut must be oriented perpendicular to the blade and anvil plane, otherwise blades can be broken or bent

- Using the gripper device attached to the shear anvil helped to eliminate misalignment of materials and blade breaking problems.

- Power source must be available at work location or extension cords must be long enough to reach the desired location

- Unit is not a stand-alone piece of equipment and should be used with other baseline methods in order to exploit the best features of each technology.

- Orientation of component being cut is sometimes critical to cut success. (e.g.; channel must be cut with back to the blade tip otherwise the channel spreads and does not cut through)

\section{Technology Limitations and Needs for Future Development}

- SRM could not cut certain configurations due to width of shear and gripper combination.

- Motorizing the base unit would reduce overall setup time and cutting time.

- A laser range pointer with a homing device on the shear head would assist in rapid placement and final maneuvering of the shear head.

- Use of flexible or expanding boots around telescoping cylinders and joints would simplify decontamination of the unit.

- An onboard computer would make it possible for the unit to automatically cycle through repetitive motions.

- A larger shear (8-inch) could easily be accommodated on the SRM in place of the current 6inch size, increasing the cutting capacity. 


\section{Technology Selection Criteria}

- This technology is suitable at DOE nuclear facilities or other D\&D sites where piping, conduit, or metal components have to be removed and size-reduced. The machine can be used in clean areas but the greatest economic benefit for size reduction would be found in contaminated areas.

- The SRD can access rooms or areas through standard 36" door openings.

- It can cut up to 4" stainless steel components including channel.

- The technology is very useful for cutting both at ground level, where components are brought to the machine, and on overhead piping and conduits, where they are cut in place.

- The technology is faster than the comparable baseline technologies.

- It provides a safer means of cutting, both overhead and at ground level. The operator does not handle the weight of the cutting tool, is located out of harm's way, and is protected from stress injury and fatigue arising from handling heavy tools. 


\section{APPENDIX A}

\section{REFERENCES}

1. Westinghouse Savannah River Company; "321-M Fuel Fabrication Facility Large Scale Demonstration \& Deployment Project; Technology Demonstration Test Plan for Size Reduction Deployment Platform"; July 26, 1999.

2. Hazardous, toxic, radioactive waste remedial action work break down structure and data dictionary. 1996. Headquarters United States Army Corps of Engineers, 20 Massachusetts Avenue, N.W., Washingtion, D.C. 20314-1000 


\section{TECHNOLOGY COST COMPARISON}

\section{Introduction}

This analysis presents realistic estimates to compare costs between an innovative technology (Size Reduction Machine) and two baseline technologies (Portable Band Saw and Hand Held Shear). The baseline represents conventional methods and equipment for pipe and component removal and size reduction.

The analysis defines activities according to the Hazardous, Toxic, Radioactive Waste Remedial Action Work Breakdown Structure and Data Dictionary (HTRW RA WBS), USACE, 1996. The HTRW RA WBS, developed by an interagency group, was used in this analysis to provide consistency with the established national standards.

Some costs are omitted from this analysis so that it more realistically reflects a typical commercial application. The general and administrative (G\&A) markup costs for the site work force are omitted from this analysis. Overhead rates for each DOE site vary in magnitude and in the way they are applied. Decision-makers seeking site-specific costs can apply their site's G\&A rate to this analysis without having to first back out the rates used at Savannah River Site.

The following assumptions were used as the basis for the INNOVATIVE TECHNOLOGY and BASELINE TECHNOLOGIES cost analyses:

- Oversight engineering, quality assurance and some administrative cost for the demonstration were not included.

- As applicable, the equipment hourly rate for the size reduction machine reflects government ownership, and is based on general guidance contained in the Office of Management and Budget's (OMB) Circular No. A-94 for Cost Effectiveness Analysis.

- Equipment unit rates (e.g., the size reduction machine and the portable band saw) are determined based on information recorded in the ACOE data collection forms.

- Equipment rental rates (e.g.; the scissors lift and the hand held shear) are based on the prevailing rates as advertised by the Savannah River Site Portable Equipment Commodity Management Center (PECMC). Equipment rental rates were used to calculate the SRM, PBS, and HHS unit rates. Commercial rates are substantially higher; their use would have resulted in higher unit costs for the baseline technologies.

- Standard labor rates established by the Savannah River Site for estimating D\&D work were used for those portions of work performed by the site's work force.

- The analysis expresses all labor on an hourly basis.

- No costs were included for equipment preparation prior to entering the contaminated area, and no costs were included for equipment decontamination once the job was completed. The time to prepare the SRM and HHS for entry into the contaminated area was approximately 8 hours each. The time to decontaminate the SRM and HHS on removal from the contaminated area was approximately 16 hours each. There was no equipment preparation or decontamination for the PBS. Once the job was completed, the PBS was disposed of as low level waste (LLW). The total cost in the PBS case was the cost of the band saw and the LLW disposal fees. SRM 
and HHS equipment preparation plus decontamination costs were essentially the same as PBS equipment cost and LLW disposal. Since the relative cost between the innovative and baseline technologies was not affected by these activities, they were not included in the cost analysis.

\section{Mobilization (WBS 33.01)}

Inspect Equipment: All equipment was inspected prior to use for each cutting method.

Use Personal Protective Equipment (PPE): Personal protective equipment was used in the High Contamination Area (HCA) and the Airborne Radioactivity Area (ARA) for all three cutting methods.

Use of B-25 or Roll-Off Scrap Container: B-25 scrap container(s) were used for disposal of contaminated metal from the HCA and ARA. Roll-off scrap container(s) were used for disposal of metal cut in the radiological buffer area (RBA) once it was verified to be free-releasable.

\section{Dismantlement - Cutting (WBS 33.17.04)}

Cut metal components: Metal components were cut (size-reduced) in two categories: loose items and overhead items, with sub-categories within these major categories. In the loose item category, both light and heavy items were cut in the HCA/ARA. In the overhead category, small and large diameter piping, unistrut, and angle iron were cut. These cut locations were located in an RBA.

\section{Demobilization (WBS 33.21)}

Remove B-25(s) or Roll-Off Scrap Container(s): Remove the B-25(s) or roll-off scrap container(s).

Equipment unit rates are calculated in Tables B-1, B-2, and B-3 of this appendix. The details of the cost analysis for the innovative and baseline technologies are summarized in Tables B-4 through B12 of this appendix. 


\section{Table B-1 Equipment Unit Rates for SRM}

\section{OPERATION}

\begin{tabular}{|c|c|c|c|c|c|c|c|}
\hline item & Equipment & $\begin{array}{c}\text { Equip- } \\
\text { ment } \\
\text { Cost }[\$]\end{array}$ & & & $\begin{array}{c}\text { Expected } \\
\text { Lifetime } \\
\text { [hrs] }\end{array}$ & & $\begin{array}{l}\text { Unit Rate }[\$ / h r] \\
\text { (w/o maint.) }\end{array}$ \\
\hline \multirow[t]{3}{*}{1} & Size Reduction Machine & $\$ 127,000$ & & & 4000 & & 31.7500 \\
\hline & MAINTENANCE & & & & & & \\
\hline & Activity & $\begin{array}{c}\text { Material } \\
\text { Cost }[\$]\end{array}$ & $\begin{array}{c}\text { Labor } \\
\text { Time } \\
\text { [mhrs] }\end{array}$ & $\begin{array}{c}\text { Labor } \\
\text { Cost }^{1}[\$]\end{array}$ & $\begin{array}{l}\text { Changes } \\
\text { over } \\
\text { Lifetime }\end{array}$ & $\begin{array}{l}\text { Cost over } \\
\text { Lifetime }[\$]\end{array}$ & $\begin{array}{c}\text { Unit Rate }[\$ / \mathrm{hr}] \\
\text { (based on } 4000 \text { hours) }\end{array}$ \\
\hline 1 & $\begin{array}{l}\text { Change hydraulic oil (for } \\
\text { shear) }\end{array}$ & $\$ 10$ & 2 & $\$ 86.50$ & 20 & $\$ 1,930$ & 0.4825 \\
\hline 2 & Change hydraulic oil (for arm) & $\$ 30$ & 2 & $\$ 86.50$ & 20 & $\$ 2,330$ & 0.5825 \\
\hline 3 & Change oil filter ${ }^{2}$ & $\$ 10$ & 0 & $\$ 0.00$ & 20 & $\$ 200$ & 0.0500 \\
\hline 4 & Change HEPA filter & $\$ 25$ & 0.5 & $\$ 21.63$ & 40 & $\$ 1,865$ & 0.4663 \\
\hline 5 & Change roughing air filter & $\$ 12$ & 0.5 & $\$ 21.63$ & 40 & $\$ 1,345$ & 0.3363 \\
\hline \multirow[t]{2}{*}{6} & Replace blades ${ }^{3,4}$ & $\$ 100$ & 1 & $\$ 43.25$ & 80 & $\$ 11,460$ & 2.8650 \\
\hline & \multicolumn{6}{|c|}{$\begin{array}{l}\text { TOTAL (equipment cost per hour } \\
(\$ / \mathrm{hr})\end{array}$} & 6.53 \\
\hline
\end{tabular}

Notes:

(1) Fully burdened mechanic charge rate is ...

(2) Oil filter change labor included in item \#2

$\$ 43.25$

per hour

(3) Based on purchase made by M. Bruns

(4) 2000 hours per work year, cut $\sim 25 \%$ of time or 500 hours, at 10 hours per day this is 10 weeks, estimated 1 blade per week, over the course of the SRM lifetime (or 8 years -500 hours X 8 ) this equates to 80 blades. Blade cost is $\$ 100$ per blade.

Table B-2 Equipment Unit Rates for PBS

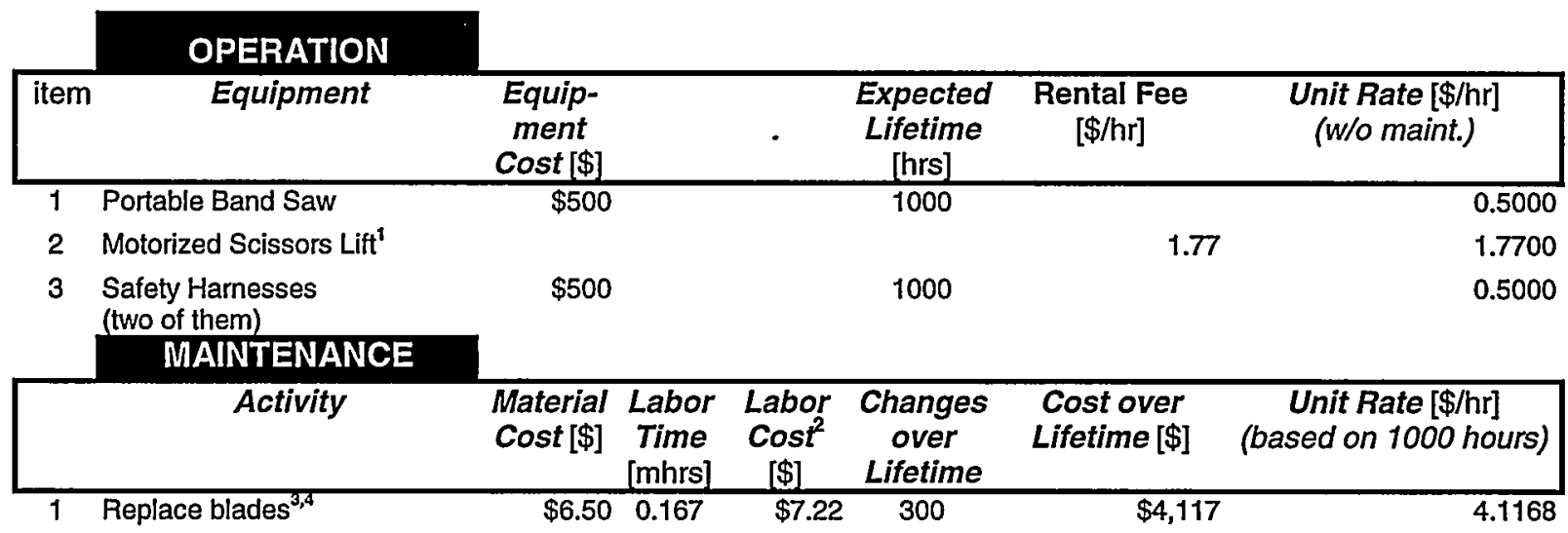

TOTAL (equipment cost per hour

Notes:

(1) Motorized scissors lift is a PECMC piece of equipment. It is a rental piece of equipment.

(2) Fully burdened mechanic charge rate is ...

$\$ 43.25$

$(\$ / \mathrm{hr})$

(3) Going rate for portable band saw blades.

(4) Empirical data indicates PBS blades replaced at a rate of 30 blades per two week period. 2000 hours per work year, cut $25 \%$ of time or 500 hours, at 10 hours per day this is 10 weeks, estimated use is 30 blades in two week period or 150 blades in 10 week period, for two years (1000 hours) this is 300 blades over the lifetime of the portable band saw. Blade cost is $\$ 6.50$ per blade. 
Table B-3 Equipment Unit Rates for HHS

\begin{tabular}{|c|c|c|c|c|c|c|c|}
\hline item & Equipment & $\begin{array}{l}\text { Equip- } \\
\text { ment } \\
\text { Cost [\$] }\end{array}$ & & & $\begin{array}{c}\text { Expected } \\
\text { Lifetime } \\
\text { [hrs] }\end{array}$ & $\begin{array}{c}\text { Rental Fee } \\
{[\$ / \mathrm{hr}]}\end{array}$ & $\begin{array}{l}\text { Unit Rate }[\$ / \mathrm{hr}] \\
\text { (w/o maint.) }\end{array}$ \\
\hline 1 & Hand Held Shear ${ }^{2}$ & & & & & 0.48 & 0.4800 \\
\hline 2 & Motorized Scissors Lift ${ }^{2}$ & & & & & 1.77 & 1.7700 \\
\hline 3 & Safety Harnesses (two of & $\$ 500$ & & & 1000 & & 0.5000 \\
\hline & Activity & $\begin{array}{l}\text { Material } \\
\text { Cost }[\$]\end{array}$ & $\begin{array}{l}\text { Labor } \\
\text { Time } \\
\text { [mhrs] }\end{array}$ & $\begin{array}{c}\text { Labor } \\
\text { Cost }^{3} \\
{[\$]}\end{array}$ & $\begin{array}{l}\text { Changes } \\
\text { over } \\
\text { Lifetime }\end{array}$ & $\begin{array}{l}\text { Cost over } \\
\text { Lifetime }[\$]\end{array}$ & $\begin{array}{c}\text { Unit Rate }[\$ / \mathrm{hr}] \\
\text { (based on } 1000 \text { hours) }\end{array}$ \\
\hline$\overline{1}$ & Replace blades ${ }^{4,5}$ & $\$ 350$ & $\frac{1}{1}$ & $\$ 43.25$ & 16 & $\$ 6,292$ & $\$ 7.8650$ \\
\hline
\end{tabular}

Notes:

(1) Hand Held Shear is a PECMC piece of equipment. It is a rental piece of equipment.

(2) Motorized scissors lift is a PECMC piece of equipment. It is a rental piece of equipment.

(3) Fully burdened mechanic charge rate is ... $\$ 43.25$ per hour.

(4) Based on SRS purchase order.

(5) 2000 hours per work year, cut $-25 \%$ of time or 500 hours, at 10 hours per day this is 10 weeks, estimated use is 1 blade per week, 10 blades per year, using an expected lifetime of 800 hours this equates to 16 blades over the lifetime of the hand held shear. Blade cost is $\$ 350$. 
Table B-4 Innovative Size Reduction Machine - Case I

\begin{tabular}{|c|c|c|c|c|c|c|c|c|c|c|c|}
\hline \multirow[t]{2}{*}{ Work Breakdown Structure (WBS) } & \multicolumn{2}{|c|}{ Labor } & \multicolumn{2}{|c|}{ Equipment } & \multirow[t]{2}{*}{ Other } & \multirow{2}{*}{$\begin{array}{l}\text { Total Quantity } \\
\text { (TQ) }\end{array}$} & \multirow{2}{*}{$\begin{array}{l}\text { Unit of } \\
\text { Measure }\end{array}$} & \multirow[t]{2}{*}{ Unit Cost } & \multirow{2}{*}{$\begin{array}{l}\text { Total Cost } \\
\text { (TC) }\end{array}$} & \multirow[t]{2}{*}{ Crew } & \multirow[t]{2}{*}{ Comments } \\
\hline & Hrs & Rate & Hrs & Rate & & & & & & & \\
\hline $\begin{array}{l}\text { Mobilization } \\
\text { (WBS 33.01) }\end{array}$ & & & & & & & & & $\$ 741.63$ & & \\
\hline Inspect Size Reduction Machine & 0.5 & $\$ 43.25$ & & & & 1 & $\mathrm{job}$ & & $\$ 21.63$ & 1 mechanic & \\
\hline $\begin{array}{l}\text { Use of personal protective } \\
\text { equipment (PPE) }\end{array}$ & & & & & $\$ 10 /$ pair & 1 & job & & $\$ 120.00$ & $\begin{array}{l}2 \text { mechaniss and } 1 \mathrm{HP} \text { tech } \\
\text { require PPES }\end{array}$ & $\begin{array}{l}\text { 2PPE changes per day, job } \\
\text { duration }=2 \text { days }\end{array}$ \\
\hline Use of B-25 & & & & & $\$ 600$ & 1 & job & & $\$ 600.00$ & & $\mathrm{~B}-25$ cost is 5600 \\
\hline $\begin{array}{l}\text { Dismantlement - Cutting } \\
\text { (WBS 33.17.04) }\end{array}$ & & & & & & & & & $\$ 79.22$ & & \\
\hline $\begin{array}{l}\text { Cut loose metal components at } \\
\text { ground level in contaminated area } \\
\text { (thin-walled components) }\end{array}$ & 1.5275 & $\$ 40.62$ & 0.47 & $\$ 36.53$ & $\begin{array}{l}\text { included in } \\
\text { equipment } \\
\text { unit rale }\end{array}$ & 34 & cuts & $\$ 2.33$ & $\$ 79.22$ & $\begin{array}{l}2 \text { mechanics, } 1 \text { supervisor, and } 1 \\
\text { HP lech. This was a } 0.47 \text { hour } \\
\text { job. }\end{array}$ & $\begin{array}{l}2 \text { mechanics - full time; } 1 \\
\text { supervisor - } 25 \% \text { of time; } 1 \mathrm{HP} \\
\text { tech - full time }\end{array}$ \\
\hline $\begin{array}{l}\text { Demobilization } \\
\text { (WBS 33.21) }\end{array}$ & & & & & & & & & $\$ 21.63$ & & \\
\hline Remove B-25 & 0.5 & $\$ 43.25$ & & & & & job & & $\$ 21.63$ & 1 mechanic & \\
\hline Total Cost & & & & & & & & & $\$ 842.47$ & & \\
\hline
\end{tabular}

NOTES \& CALCULATIONS:

(1) Rigging not required for the PBS and HHS baseline technologies; therefore, no rigging was included for the SRM.

(2) One B-25 waste container was used for this portion of the Size Reduction tech demo.

(3) Fully burdened charge rates: mechanic - $\$ 43.25$ per hour

$$
\begin{aligned}
& \text { supervisor }-\$ 62.00 \text { per hour } \\
& \text { HP tech }-\$ 30.00 \text { per hour }
\end{aligned}
$$

(4) $[.47 \mathrm{~h} \times 2$ mechanics $]+[.47 \mathrm{~h} \times .25$ supevisor $]+[.47 \mathrm{~h} \times 1 \mathrm{HP}$ tech $]=1.5275$ hours

(5) $([.47 \mathrm{~h} \times 2$ mechanics $\times \$ 43.25 / \mathrm{h}]+[.47 \mathrm{~h} \times .25$ supervisor $\times \$ 62 \mathrm{~h}]+[.47 \mathrm{~h} \times 1 \mathrm{HP}$ tech $\times \$ 30 \mathrm{~h})) / 1.5275 \mathrm{~h}=\$ 40.62 /$ hour

$\begin{array}{ll}\text { (6) Examples of items cul: } & \text { 1-inch diameter, schedule } 10 \text { tubing } \\ 1 \text {-inch square, schedule } 10 \text { tubing }\end{array}$ 
Table B-5 Innovative Size Reduction Machine - Case II

\begin{tabular}{|c|c|c|c|c|c|c|c|c|c|c|c|}
\hline \multirow[t]{2}{*}{ Work Breakdown Structure (WBS) } & \multicolumn{2}{|c|}{ Labor } & \multicolumn{2}{|c|}{ Equipment } & \multirow[t]{2}{*}{ Other } & \multirow{2}{*}{$\begin{array}{l}\text { Total Quantity } \\
\text { (TQ) }\end{array}$} & \multirow{2}{*}{$\begin{array}{l}\text { Unit of } \\
\text { Measure }\end{array}$} & \multirow[t]{2}{*}{ Unit cost } & \multirow{2}{*}{$\begin{array}{l}\text { Total Cost } \\
\text { (TC) }\end{array}$} & \multirow[t]{2}{*}{ Crew } & \multirow[t]{2}{*}{ Comments } \\
\hline & Hirs & Rate. & His & Rate & & & & & & & \\
\hline $\begin{array}{l}\text { Mobilization } \\
\text { (WBS 33.01) }\end{array}$ & & & & & & & & & $\$ 801.63$ & & \\
\hline Inspect Size Reduction Machine & 0.5 & $\$ 43.25$ & & & & 1 & job & & $\$ 21.63$ & 1 mechanic & \\
\hline $\begin{array}{l}\text { Use of personal protective } \\
\text { equipment (PPE) }\end{array}$ & & & & & \$10/pair & 1 & job & & $\$ 180.00$ & $\begin{array}{l}2 \text { mechanics and } 1 \mathrm{HP} \text { tech } \\
\text { require PPEs }\end{array}$ & $\begin{array}{l}2 \text { PPE changes per day, job } \\
\text { duration }=3 \text { days }\end{array}$ \\
\hline Use of B.25 & & & & & $\$ 600$ & 1 & job & & $\$ 600.00$ & & B-25 cost is $\$ 600$ \\
\hline $\begin{array}{l}\text { Dismantlement - Cutting } \\
\text { (WBS 33.17.04) }\end{array}$ & & & & & & & & & $\$ 502.26$ & & \\
\hline $\begin{array}{l}\text { Cut loose melal components at } \\
\text { ground level in contaminated area } \\
\text { (heavy structural shapes) }\end{array}$ & 9.6850 & $\$ 40.62$ & 2.98 & $\$ 36.53$ & $\begin{array}{l}\text { included in } \\
\text { equipment } \\
\text { unit rate }\end{array}$ & 59 & culs & $\$ 8.51$ & $\$ 502.26$ & $\begin{array}{l}2 \text { mechanics, } 1 \text { supervisor, and } 1 \\
\text { HP tech. This was a } 2.98 \text { hour } \\
\text { job. }\end{array}$ & $\begin{array}{l}2 \text { mechanics - full time; } 1 \\
\text { supervisor - } 25 \% \text { of time; } 1 \mathrm{HP} \\
\text { tech - full time }\end{array}$ \\
\hline $\begin{array}{l}\text { Demobillization } \\
\text { (WBS 33.21) }\end{array}$ & & & & & & & & & $\$ 21.63$ & & \\
\hline Remove B-25 & 0.5 & $\$ 43.25$ & & & & & job & & $\$ 21.63$ & 1 mechanic & \\
\hline Total Cost & & & & & & & & & $\$ 1,325.51$ & & \\
\hline
\end{tabular}

\section{NOTES \& CALCULATIONS:}

(1) Rigging not required for the PBS and HHS baseline technologies; therefore, no rigging was included for the SRM.

(2) One B-25 waste container was used for this portion of the Size Reduction tech demo.

(3) Fully burdened charge rales: mechanic $-\$ 43.25$ per hour

supervisor - $\$ 2.00$ perhour

(4) $[2.98 \mathrm{~h} \times 2$ mechanics $]+[2.98 \mathrm{~h} \times .25$ supervisor $]+[2.98 \mathrm{~h} \times 1 \mathrm{HP}$ tech $]=9.685$ hours

(4) $(2.90 \times 2$.

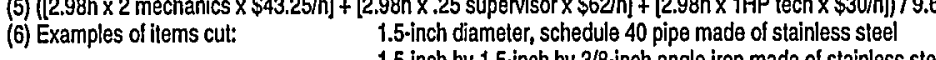

4 -inch by 1 and $5 / 8$-inch by $3 / 8$-inch channel made of staintess steel 
Table B-6 Innovative Size Reduction Machine - Case III

\begin{tabular}{|c|c|c|c|c|c|c|c|c|c|c|c|}
\hline \multirow[t]{2}{*}{ Work Breakdown Structure (WBS) } & \multicolumn{2}{|c|}{ Labor } & \multicolumn{2}{|c|}{ Equipment } & \multirow[t]{2}{*}{ Other } & \multirow{2}{*}{$\begin{array}{l}\text { Total Quantity } \\
\text { (TQ) }\end{array}$} & \multirow{2}{*}{$\begin{array}{l}\text { Unit of } \\
\text { Measure }\end{array}$} & \multirow[t]{2}{*}{ Unit Cost } & \multirow{2}{*}{$\begin{array}{l}\text { Total Cost } \\
\text { (TC) }\end{array}$} & \multirow[t]{2}{*}{ Crew } & \multirow[t]{2}{*}{ Comments } \\
\hline & His & Rate & Hirs & Rate & & & & & & & \\
\hline $\begin{array}{l}\text { Mobilization } \\
\text { (WBS 33.01) }\end{array}$ & & & & & & & & & $\$ 89.88$ & & \\
\hline Inspect Size Reduction Machine & 0.5 & $\$ 43.25$ & & & & 1 & job & & $\$ 21.63$ & 1 mechanic & \\
\hline Provide roll-off scrap container & 1 & $\$ 43.25$ & 5 days & $\$ 5 /$ day & & 1 & $\mathrm{job}$ & & $\$ 68.25$ & 1 mechanic & Job duration $=5$ days \\
\hline $\begin{array}{l}\text { Dismantlement - Cutting } \\
\text { (WBS 33.17.04) }\end{array}$ & & & & & & & & & $\$ 461.28$ & & \\
\hline $\begin{array}{l}\text { Cut overhead fixed items in clean } \\
\text { area) }\end{array}$ & 7.4925 & $\$ 45.33$ & 3.33 & $\$ 36.53$ & $\begin{array}{l}\text { included in } \\
\text { equipment } \\
\text { unit rate }\end{array}$ & 71 & culs & $\$ 6.50$ & $\$ 461.28$ & $\begin{array}{l}2 \text { mechanics, } 1 \text { supervisor. This } \\
\text { was a } 3.33 \text { hour job. }\end{array}$ & $\begin{array}{l}2 \text { mechanics - full time; } 1 \\
\text { supervisor - } 25 \% \text { of time }\end{array}$ \\
\hline $\begin{array}{l}\text { Demobilization } \\
\text { (WBS 33.21) }\end{array}$ & & & & & & & & & $\$ 21.63$ & & \\
\hline Remove roll-off scrap container & 0.5 & $\$ 43.25$ & & & & & job & & $\$ 21.63$ & 1 mechanic & \\
\hline Total Cost & & & & & & & & & $\$ 572.78$ & & \\
\hline
\end{tabular}

(1) Rigging not required for the PBS and HHS baseline technologies; therefore, no rigging was included for the SRM.

(2) Roll-off scrap container is leased from PECMC at the rate of $\$ 5 /$ day.

(3) Fully burdened charge rates: mechanic $-\$ 43.25$ per hour

supervisor $-\$ 62.00$ per hour

(4) $[3.33 \mathrm{~h} \times 2$ mechanics] $+[3.33 \mathrm{~h} \times 25$ supenis $]=7.4025$ hour

(5) $([3.33 \mathrm{~h} \times 2$ mechanics $\times \$ 43.25 / \mathrm{h}]+[3.33 \mathrm{~h} \times .25$ supevisor $\times \$ 62 / \mathrm{h})) / 7.4925 \mathrm{~h}=\$ 45.33 / \mathrm{hour}$

(5) $((3.33 \mathrm{~h} \times 2$ mechanics $\times \$ 43.25 / \mathrm{h}]+[3.33 \mathrm{~h} \times .25$ supevisor $\times \$ 62 / \mathrm{h}) / 7.4925 \mathrm{~h}=\$ 45.33 / \mathrm{hour}$
(6) Examples of items cut:
3/4-inch diameter, schedule 40 pipe made of carbon steel

1.5-inch diameter, schedule 40 pipe made of carbon steel

2.5 -inch by 2 -inch, schedule 20 unistrut made of carbon steel

1.5 -inch by 1.5 -inch by $1 / 4$-inch angle iron made of carbon steel

1/2-inch diameter rod made of carbon steel 
Table B-7 Baseline Portable Band Saw - Case I

\begin{tabular}{|c|c|c|c|c|c|c|c|c|c|c|c|}
\hline \multirow{2}{*}{ Work Breakdown Structure (WBS) } & \multicolumn{2}{|c|}{ Labor } & \multicolumn{2}{|c|}{ Equipment } & \multirow[t]{2}{*}{ Other } & \multirow{2}{*}{$\begin{array}{l}\text { Total Quantity } \\
\text { (TQ) }\end{array}$} & \multirow{2}{*}{$\begin{array}{c}\text { Unit of } \\
\text { Measure }\end{array}$} & \multirow[t]{2}{*}{ Unit Cost } & \multirow{2}{*}{$\begin{array}{l}\text { Tolal Cost } \\
\text { (TC) }\end{array}$} & \multirow[t]{2}{*}{ Crew } & \multirow[t]{2}{*}{ Comments } \\
\hline & His & Rate & Hirs & Rate & & & & & & & \\
\hline $\begin{array}{l}\text { Mobilization } \\
\text { (WBS 33.01) }\end{array}$ & & & & & & & & & $\$ 741.63$ & & \\
\hline Inspect Portable Band Saw & 0.5 & $\$ 43.25$ & & & & 1 & job & & $\$ 21.63$ & 1 mechanic & \\
\hline $\begin{array}{l}\text { Use of personal protective } \\
\text { equipment (PPE) }\end{array}$ & & & & & $\$ 10 / p a i r$ & 1 & job & & $\$ 120.00$ & $\begin{array}{l}2 \text { mechanics and } 1 \mathrm{HP} \text { tech } \\
\text { require PPES }\end{array}$ & $\begin{array}{l}\text { 2PPE changes per day, job } \\
\text { duration }=2 \text { days }\end{array}$ \\
\hline Use of $\mathrm{B} \cdot 25$ & & & & & $\$ 600$ & 1 & job & & $\$ 600.00$ & & B. 25 cost is $\$ 600$ \\
\hline $\begin{array}{l}\text { Dismantlement - Cutting } \\
\text { (WBS 33.17.04) }\end{array}$ & & & & & & & & & $\$ 186.13$ & & \\
\hline $\begin{array}{l}\text { Cut loose melal components at } \\
\text { ground level in contaminated area } \\
\text { (thin-walled components) }\end{array}$ & 4.3550 & $\$ 40.62$ & 1.34 & $\$ 6.89$ & $\begin{array}{l}\text { included in } \\
\text { equipment } \\
\text { unit rale }\end{array}$ & 34 & cuts & $\$ 5.47$ & $\$ 186.13$ & $\begin{array}{l}2 \text { mechanics, } 1 \text { supervisor, and } 1 \\
\text { HP tech. This was a } 1.34 \text { hour } \\
\text { job. }\end{array}$ & $\begin{array}{l}2 \text { mechaniss - full time; } 1 \\
\text { supervisor - } 25 \% \text { of time; } 1 \mathrm{HP} \\
\text { tech - full time }\end{array}$ \\
\hline $\begin{array}{l}\text { Demobillizatlon } \\
\text { (WBS 33.21) }\end{array}$ & & & & & & & & & $\$ 21.63$ & & \\
\hline Remove B-25 & 0.5 & $\$ 43.25$ & & & & & job & & $\$ 21.63$ & 1 mechanic & \\
\hline Total Cost & & & & & & & & & $\$ 9949.38$ & & \\
\hline
\end{tabular}

\section{NOTES \& CALCULATIONS:}

(1) Rigging not required for the PBS and HHS baseline technologies; therefore, no rigging was included for the SRM.

waste container was used to containerize waste from the PBS cuts.

(3) Fully burdened charge rales: mechanic $\$ 43.25$ per hour

supervisor - $\$ 62.00$ per hour

(4) $[1.34 \mathrm{~h} \times 2$ mechanics $]+[1.34 \mathrm{~h} \times .25$ superisor $]+[1.34 \mathrm{~h} \times 1 \mathrm{HP}$ tech $]=4.3550$ hours

(5) $(11.34 \mathrm{~h} \times 2$ mechanics $\times \$ 43.25 / \mathrm{h}]+[1.34 \mathrm{~h} \times .25$ supenisor $\times \$ 62 \mathrm{~h}]+[1.34 \mathrm{~h} \times 1 \mathrm{HP}$ tech $\times \$ 30 \mathrm{~h})] / 4.355 \mathrm{~h}=\$ 40.62 /$ hour

(6) Examples of items cut: $\quad$-inch diameter, schedule 10 tubing

(6) Examples of items cut: $\quad$ T-inch diameter, schedule to tubing

t-inch diameter, threaded and hardened rod 
Table B-8 Baseline Portable Band Saw - Case II

\begin{tabular}{|c|c|c|c|c|c|c|c|c|c|c|c|}
\hline \multirow[t]{2}{*}{ Work Breakdown Structure (WBS) } & \multicolumn{2}{|c|}{ Labor } & \multicolumn{2}{|c|}{ Equipment } & \multirow[t]{2}{*}{ Other } & \multirow{2}{*}{$\begin{array}{c}\text { Total Quantity } \\
\text { (TQ) }\end{array}$} & \multirow{2}{*}{$\begin{array}{l}\text { Unit of } \\
\text { Measure }\end{array}$} & \multirow[t]{2}{*}{ Unit Cost } & \multirow{2}{*}{$\begin{array}{l}\text { Total Cost } \\
\text { (TC) }\end{array}$} & \multirow[t]{2}{*}{ Crew } & \multirow[t]{2}{*}{ Comments } \\
\hline & Hrs & Rate & Hrs & Rale & & & & & & & \\
\hline $\begin{array}{l}\text { Mobilizatlon } \\
\text { (WBS 33.01) }\end{array}$ & & & & & & & & & $\$ 801.63$ & & \\
\hline Inspect Portable Band Saw & 0.5 & $\$ 43.25$ & & & & 1 & job & & $\$ 21.63$ & 1 mechanic & \\
\hline $\begin{array}{l}\text { Use of personal prolective } \\
\text { equipment (PPE) }\end{array}$ & & & & & $\$ 10 / p a i r$ & 1 & $\mathrm{job}$ & & $\$ 180.00$ & $\begin{array}{l}2 \text { mechanics and } 1 \mathrm{HP} \text { lech } \\
\text { require PPES }\end{array}$ & $\begin{array}{l}2 \text { PPE changes per day, job } \\
\text { duration }=3 \text { days }\end{array}$ \\
\hline Use of B-25 & & & & & $\$ 600$ & 1 & job & & $\$ 600.00$ & & B. 25 cost is $\$ 600$ \\
\hline $\begin{array}{l}\text { Dismantlement - Cutting } \\
\text { WBS 33.17.04) }\end{array}$ & & & & & & & & & $\$ 444.50$ & & \\
\hline $\begin{array}{l}\text { Cut loose metal components at } \\
\text { ground level in contaminated area } \\
\text { (heavy structural shapes) }\end{array}$ & 10.40 & $\$ 40.62$ & 3.20 & $\$ 6.89$ & $\begin{array}{l}\text { included in } \\
\text { equipment } \\
\text { unit rate }\end{array}$ & 59 & culs & $\$ 7.53$ & $\$ 444.50$ & $\begin{array}{l}2 \text { mechanics, } 1 \text { supervisor, and } 1 \\
\text { HP tech. This was a } 3.2 \text { hour job. }\end{array}$ & $\begin{array}{l}2 \text { mechanics - full time; } 1 \\
\text { supervisor - } 25 \% \text { of time; } 1 \mathrm{HP} \\
\text { lech - full time }\end{array}$ \\
\hline $\begin{array}{l}\text { Demobillization } \\
\text { (WBS 33.21) }\end{array}$ & & & & & & & & & $\$ 21.63$ & & \\
\hline Remove B-25 & 0.5 & $\$ 43.25$ & & & & & $\mathrm{job}$ & & $\$ 21.63$ & 1 mechanic & \\
\hline Total Cost & & & & & & & & & $\$ 1,267.75$ & & \\
\hline
\end{tabular}

NOTES \& CALCULATIONS:

(1) Rigging not required for the PBS and HHS baseline technologies; therefore, no rigging was included for the SRM.

(2) One B-25 waste container was used to containerize waste from the PBS cuts.

(3) Fully burdened charge rates: mechanic $-\$ 43.25$ per hour

$$
\text { supervisor }-\$ 62.00 \text { per hour }
$$

HP tech $-\$ 30.00$ per hour

(4) $[3.20 \mathrm{~h} \times 2$ mechanics $]+[3.20 \mathrm{~h} \times .25$ supervisor $]+[3.20 \mathrm{~h} \times 1 \mathrm{HP}$ tech $]=10.40$ hours

(5) (3.20h $\times 2$ mechanics $\times \$ 43.25 \mathrm{~h}]+[3.20 \mathrm{~h} \times .25$ supenvisor $\times \$ 62 \mathrm{~h}]+(3.20 \mathrm{~h} \times 1 \mathrm{HP}$ tech $\times \$ 30 \mathrm{~h})) / 10.40 \mathrm{~h}=\$ 40.62 /$ hour

(6) Examples of items cut: $\quad 1.5$-inch diameter, schedule 40 pipe made of stainless sleel

1.5 -inch by 1.5 -inch by $3 / 8$-inch angle iron made of stainless steel

4 -inch by 1 and $5 / 8$-inch by $3 / 8$-inch channel made ol stainless steel 
Table B-9 Baseline Portable Band Saw - Case III

\begin{tabular}{|c|c|c|c|c|c|c|c|c|c|c|c|}
\hline \multirow[t]{2}{*}{ Work Breakdown Structure (WBS) } & \multicolumn{2}{|c|}{ Labor } & \multicolumn{2}{|c|}{ Equipment } & \multirow[t]{2}{*}{ Other } & \multirow{2}{*}{$\begin{array}{l}\text { Total Quantity } \\
\text { (TQ) }\end{array}$} & \multirow{2}{*}{$\begin{array}{l}\text { Unit of } \\
\text { Measure }\end{array}$} & \multirow[t]{2}{*}{ Unit Cost } & \multirow{2}{*}{$\begin{array}{l}\text { Total Cost } \\
\text { (TC) }\end{array}$} & \multirow[t]{2}{*}{ Grew } & \multirow[t]{2}{*}{ Comments } \\
\hline & Hrs & Rate & His & Rate & & & & & & & \\
\hline $\begin{array}{l}\text { Mobilization } \\
\text { (WBS 33.01) }\end{array}$ & & & & & & & & & $\$ 89.88$ & & \\
\hline Inspect Portable Band Saw & 0.5 & $\$ 43.25$ & & & & 1 & job & & $\$ 21.63$ & 1 mechanic & \\
\hline Provide roll-olf scrap container & 1 & $\$ 43.25$ & 5 days & $\$ 5 /$ day & & 1 & job & & $\$ 68.25$ & 1 mechanic & Job duration $=5$ days \\
\hline $\begin{array}{l}\text { Dismantlement - Cutting } \\
\text { (WBS 33.17.04) }\end{array}$ & & & & & & & & & $\$ 547.68$ & & \\
\hline $\begin{array}{l}\text { Cut overhead fixed items in clean } \\
\text { area) }\end{array}$ & 11.700 & $\$ 44.69$ & 3.60 & $\$ 6.89$ & $\begin{array}{l}\text { included in } \\
\text { equipment } \\
\text { unit rale }\end{array}$ & 71 & culs & $\$ 7.71$ & $\$ 547.68$ & $\begin{array}{l}3 \text { mechanics, } 1 \text { supervisor. This } \\
\text { was a } 3.60 \text { hour job. }\end{array}$ & $\begin{array}{l}3 \text { mechanics - full time; } \\
1 \text { supervisor - } 25 \% \text { of time }\end{array}$ \\
\hline $\begin{array}{l}\text { Demobilization } \\
\text { (WBS 33.21) }\end{array}$ & & & & & & & & & $\$ 21.63$ & & \\
\hline Remove roll-off scrap container & 0.5 & $\$ 43.25$ & & & & & job & & $\$ 21.63$ & 1 mechanic & \\
\hline Total Cost & & & & & & & & & $\$ 659.18$ & & \\
\hline
\end{tabular}

\section{NOTES \& CALCULATIONS:}

(1) Rigging not required for the PBS and HHS baselina technologies; therefore, no rigging was included for the SRM.

(2) Roll-off scrap container is leased from PECMC at the rate of $\$ 5 /$ day.

(3) Fully burdened charge rates: mechanic - $\$ 43.25$ per hour

supenisor $-\$ 62.00$ per hour

HP tech $-\$ 30.00$ per hour

(4) $[3.60 \mathrm{~h} \times 3$ mechanics $]+[3.60 \mathrm{~h} \times .25$ supervisor $]=11.70$ hours

(5) $([3.60 \mathrm{~h} \times 3$ mechanics $\times \$ 43.25 / \mathrm{h}]+[3.60 \mathrm{~h} \times .25$ supervisor $\times \$ 62 / \mathrm{h}) / 11.70 \mathrm{~h}=\$ 44.69 / \mathrm{hour}$

(6) Examples of items cul: $\quad 3 / 4$-inch diameter, schedule 40 pipe made of carbon steel

1.5 -inch diameter, schedule 40 pipe made of carbon steel

2.5-inch by 2-inch, schedule 20 unistrut made of carbon steel

1.5.nch by 1.5 -inch by $1 / 4$-inch angle iron made of carbon steel 
Table B-10 Hand Held Shear - Case I

\begin{tabular}{|c|c|c|c|c|c|c|c|c|c|c|c|}
\hline \multirow[t]{2}{*}{ Work Breakdown Structure (WBS) } & \multicolumn{2}{|c|}{ Labor } & \multicolumn{2}{|c|}{ Equipment } & \multirow[t]{2}{*}{ Other } & \multirow{2}{*}{$\begin{array}{c}\text { Total Quantity } \\
\text { (TQ) }\end{array}$} & \multirow{2}{*}{$\begin{array}{c}\text { Unit of } \\
\text { Measure }\end{array}$} & \multirow[t]{2}{*}{ Unit Cost } & \multirow{2}{*}{$\begin{array}{l}\text { Total Cost } \\
\text { (TC) }\end{array}$} & \multirow[t]{2}{*}{ Crew } & \multirow[t]{2}{*}{ Comments } \\
\hline & Hirs & Rate & Hirs & Rate & & & & & & & \\
\hline $\begin{array}{l}\text { Mobilizalion } \\
\text { (WBS 33.01) }\end{array}$ & & & & & & & & & $\$ 741.63$ & & \\
\hline Inspect Hand Held Shear & 0.5 & $\$ 43.25$ & & & & 1 & $\mathrm{job}$ & & $\$ 21.63$ & 1 mechanic & \\
\hline $\begin{array}{l}\text { Use of personal protective } \\
\text { equipment (PPE) }\end{array}$ & & & & & \$10/pair & $\frac{1}{1}$ & job & & $\$ 120.00$ & $\begin{array}{l}2 \text { mechanies and } 1 \mathrm{HP} \text { tech } \\
\text { require PPEs }\end{array}$ & $\begin{array}{l}\text { 2PPE changes per day, job } \\
\text { duration }=2 \text { days }\end{array}$ \\
\hline Use of B-25 & & & & & $\$ 600$ & 1 & job & & $\$ 600.00$ & & $\mathrm{~B}-25$ cost is $\$ 600$ \\
\hline $\begin{array}{l}\text { Dismantlement - Cutting } \\
\text { (WBS 33.17.04) }\end{array}$ & & & & & & & & & $\$ 109.83$ & & \\
\hline $\begin{array}{l}\text { Cut loose metal components at } \\
\text { ground level in contaminated area } \\
\text { (thin-walled components) }\end{array}$ & 2.5025 & $\$ 40.62$ & 0.77 & $\$ 10.62$ & $\begin{array}{l}\text { included in } \\
\text { equipment } \\
\text { unit rale }\end{array}$ & 34 & cuts & $\$ 3.23$ & $\$ 109.83$ & $\begin{array}{l}2 \text { mechanics, } 1 \text { supervisor, and } 1 \\
\text { HP tech. This was a } 0.77 \text { hour } \\
\text { job. }\end{array}$ & $\begin{array}{l}2 \text { mechanics - full time; } 1 \\
\text { supervisor - } 25 \% \text { of time; } 1 \text { HP } \\
\text { tech - full time }\end{array}$ \\
\hline $\begin{array}{l}\text { Demobilization } \\
\text { (WBS 33,21) }\end{array}$ & & & & & & & & & $\$ 21.63$ & & \\
\hline$\frac{(m B S 03.21)}{\text { Remove B-25 }}$ & 0.5 & $\$ 43.25$ & & & & & job & & $\$ 21.63$ & 1 mechanic & \\
\hline Total Cost & & & & & & & & & $\$ 873.08$ & & \\
\hline
\end{tabular}

\section{NOTES \& CALCULATIONS:}

(1) Rigging not required for the PBS and HHS baseline technologies; therefore, no rigging was included for the SRM.

ner was used to containerize waste from the HHS culs.

(3) Fully burdened charge rates: mechanic $-\$ 43.25$ per hour

supervisor $-\$ 62.00$ per hou

(4) $[.77 \mathrm{~h} \times 2$ mechanics $]+[.77 \mathrm{~h} \times .25$ superisor $]+[.77 \mathrm{~h} \times 1 \mathrm{HP}$ lech $]=2.5025$ hours
(5) $([.77 \mathrm{~h} \times 2$ mechanics $\times \$ 43.25 / \mathrm{h}]+[.77 \mathrm{~h} \times .25$ supenvisor $\times \$ 62 / \mathrm{h}]+[.77 \mathrm{~h} \times 1 \mathrm{HP}$ lech $\times \$ 30 \mathrm{~h}]) / 2.5025 \mathrm{~h}=\$ 40.62 /$ hour

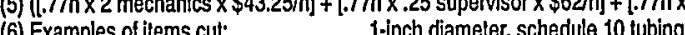

(6) Examples of items cut: $\quad$ - tinch diameier, schedule 10 fubing

1.inch diane, sched 
Table B-11 Hand Held Shear - Case II

\begin{tabular}{|c|c|c|c|c|c|c|c|c|c|c|c|}
\hline \multirow[t]{2}{*}{ Work Breakdown Structure (WBS) } & \multicolumn{2}{|c|}{ Labor } & \multicolumn{2}{|c|}{ Equipment } & \multirow[t]{2}{*}{ Other } & \multirow{2}{*}{$\begin{array}{l}\text { Total Quantity } \\
\text { (TQ) }\end{array}$} & \multirow{2}{*}{$\begin{array}{l}\text { Unit of } \\
\text { Measure }\end{array}$} & \multirow[t]{2}{*}{ Unit Cost } & \multirow{2}{*}{$\begin{array}{l}\text { Total Cost } \\
\text { (TC) }\end{array}$} & \multirow[t]{2}{*}{ Crew } & \multirow[t]{2}{*}{ Comments } \\
\hline & Hirs & Rate & $\overrightarrow{\mathrm{Hrs}}$ & Rate & & & & & & & \\
\hline $\begin{array}{l}\text { Mobilization } \\
\text { (WBS 33.01) }\end{array}$ & & & & & & & & & $\$ 801.63$ & & \\
\hline Inspect Hand Held Shear & 0.5 & $\$ 43.25$ & & & & 1 & job & & $\$ 21.63$ & 1 mechanic & \\
\hline $\begin{array}{l}\text { Use of personal protective } \\
\text { equipment (PPE) }\end{array}$ & & & & & \$10/pair & 1 & job & & $\$ 180.00$ & $\begin{array}{l}2 \text { mechanics and } 1 \mathrm{HP} \text { tech } \\
\text { require PPES }\end{array}$ & $\begin{array}{l}2 \text { PPE changes per day, job } \\
\text { duration }=3 \text { days }\end{array}$ \\
\hline Use of $B-25$ & & & & & $\$ 600$ & 1 & job & & $\$ 600.00$ & & B- $25 \cos t$ is $\$ 600$ \\
\hline $\begin{array}{l}\text { Dismantlement - Cutting } \\
\text { (WBS 33.17.04) }\end{array}$ & & & & & & & & & $\$ 445.02$ & & \\
\hline $\begin{array}{l}\text { Cut loose metal components at } \\
\text { ground level in contaminated area } \\
\text { (heavy structural shapes) }\end{array}$ & 10.14 & $\$ 40.62$ & 3.12 & $\$ 10.62$ & $\begin{array}{l}\text { included in } \\
\text { equipment } \\
\text { unit rate }\end{array}$ & 49 & cuis & $\$ 9.08$ & $\$ 445.02$ & $\begin{array}{l}2 \text { mechanics, } 1 \text { supervisor, and } 1 \\
\text { HP lech. This was a } 3.12 \text { hour } \\
\text { job. }\end{array}$ & $\begin{array}{l}2 \text { mechanics - full time; } 1 \\
\text { supervisor - } 25 \% \text { of time; } 1 \mathrm{HP} \\
\text { tech - full time }\end{array}$ \\
\hline $\begin{array}{l}\text { Demobilization } \\
\text { (WBS 33.21) }\end{array}$ & & & & & & & & & $\$ 21.63$ & & \\
\hline Remove B-25 & 0.5 & $\$ 43.25$ & & & & & $\mathrm{job}$ & & $\$ 21.63$ & 1 mechanic & \\
\hline Total Cost & & & & & & & & & $\$ 1,268.27$ & & \\
\hline
\end{tabular}

NOTES \& CALCULATIONS:

(1) Rigging

(2) Fill bute wasto contaner was used to conlantize waste from the HiS cuts.

(3) Fully burdened charge rates: mechanic - $\$ 43.25$ per hour

uP

(4) $[3.12 \mathrm{~h} \times 2$ mechanics $]+[3.12 \mathrm{~h} \times .25$ supervisor $]+[3.12 \mathrm{~h} \times 1 \mathrm{HP}$ tech $]=10.14$ hours

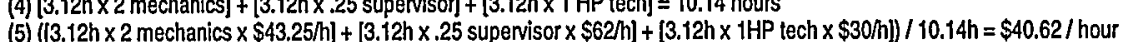

(6) Examples of items cul: $\quad$ 1.5.inch diameter, schedule 40 pipe made of stainless steel

1.5 -inch by 1.5 -inch by $3 / 8$-inch angle iron made of stainless steel

4-inch by 1 and $5 / 8$-inch by $3 / 8$-inch channel made of stainless steel 
Table B-12 Hand Held Shear - Case III

\begin{tabular}{|c|c|c|c|c|c|c|c|c|c|c|c|}
\hline \multirow[t]{2}{*}{ Work Breakdown Structure (WBS) } & \multicolumn{2}{|c|}{ Labor } & \multicolumn{2}{|c|}{ Equipment } & \multirow[t]{2}{*}{ Other } & \multirow{2}{*}{$\begin{array}{l}\text { Total Quantity } \\
\text { (TQ) }\end{array}$} & \multirow{2}{*}{$\begin{array}{l}\text { Unit of } \\
\text { Measure }\end{array}$} & \multirow[t]{2}{*}{ Unit Cost } & \multirow{2}{*}{$\begin{array}{l}\text { Total Cost } \\
\text { (TC) }\end{array}$} & \multirow[t]{2}{*}{ Crew } & \multirow[t]{2}{*}{ Comments } \\
\hline & His & Rate & His & Rate & & & & & & & \\
\hline $\begin{array}{l}\text { Mobilization } \\
\text { (WBS 33.01) }\end{array}$ & & & & & & & & & $\$ 89.88$ & & \\
\hline Inspect Hand Held Shear & 0.5 & $\$ 43.25$ & & & & 1 & $\mathrm{job}$ & & $\$ 21.63$ & 1 mechanic & \\
\hline Provide roll-off scrap container & 1 & $\$ 43.25$ & 5 days & 55/day & & 1 & job & & $\$ 68.25$ & 1 mechanic & Job duration $=5$ days \\
\hline $\begin{array}{l}\text { Dismantlement - Cutting } \\
\text { (WBS } 33.17 .04 \text { ) }\end{array}$ & & & & & & & & & $\$ 737.23$ & & \\
\hline $\begin{array}{l}\text { Cut overhead fixed items in clean } \\
\text { area }\end{array}$ & 15.3725 & $\$ 44.69$ & 4.73 & $\$ 10.62$ & $\begin{array}{l}\text { included in } \\
\text { equipment } \\
\text { unit rate }\end{array}$ & 71 & cuts & $\$ 10.38$ & $\$ 737.23$ & $\begin{array}{l}3 \text { mechanics, } 1 \text { supervisor. This } \\
\text { was a } 4.73 \text { hour job. }\end{array}$ & $\begin{array}{l}3 \text { mechanics - full time; } \\
1 \text { supervisor - } 25 \% \text { of time }\end{array}$ \\
\hline $\begin{array}{l}\text { Demobilization } \\
\text { (WBS 33.21) }\end{array}$ & & & & & & & & & $\$ 21.63$ & & \\
\hline Remove roll-off scrap container & 0.5 & $\$ 43.25$ & & & & & job & & $\$ 21.63$ & 1 mechanic & \\
\hline Total Cost & & & & & & & & & 5848.73 & & \\
\hline
\end{tabular}

NOTES \& CALCULATIONS:

(1) Rigging not required for the PBS and HHS baseline technologies; therefore, no rigging was included for the SRM.

(3) Fully burdened charge rates: mechanic - $\$ 43.25$ per hour

supervisor $-\$ 62.00$ per hou

(4) $[4.73 \mathrm{~h} \times 3$ mechanics $]+[4.73 \mathrm{~h} \times .25$ supervisor $]=15.3725$ hours

(5) $([4.73 \mathrm{~h} \times 3$ mechanics $\times \$ 43.25 / \mathrm{h}]+[4.73 \mathrm{~h} \times .25$ supervisor $\times \$ 62 / \mathrm{h})] / 15.3725 \mathrm{~h}=\$ 44.69 /$ hour

(6) Examples of items cut: $\quad 3 / 4$-inch diameter, schedule 40 pipe made of carbon steel

1.5. Inch diameter, schedule 40 pipe made of carbon steel

2.5 -inch by 2 -inch, schedule 20 unistrut made of carbon steel
1.5 -inch by 1.5 -inch by $1 / 4$-inch angle iron made of carbon steel 